\title{
The COVID-19 Pandemic, the Empowering Olympic, Paralympic and Amateur Athletes Act, and the Dawn of a New Age of U.S. Olympic Reform
}

\begin{abstract}
Mark Conrad
In the fall of 2020, Congress enacted the first substantive changes in the governance of the Olympic Sports system in over four decades. The new law, The Empowering Olympic, Paralympic and Amateur Athletes Act, was passed in the wake of sexual abuse scandals that rocked certain sport governing bodies. In amending the 1978 Amateur Sports Act, the new law grants Congress the power to decertify the United States Olympic bodies, mandates greater athlete representation in governance, and increases funding to protect athletes through greater support of the U.S. Center for SafeSport. Aside from the decertification power, the most significant provision of the new law is the establishment of a Commission on the State of U.S. Olympics and Paralympics to review the governance of the United States Olympic and Paralympic Committee ("USOPC") and make proposals for change. The Commission's creation comes at a crucial time in U.S. Olympic governance. Due to the governance scandals, uncertain funding and the general national sports upheaval caused by the COVID-19 pandemic, this article advocates for more significant changes to the Olympic structure that the commission should consider, such as direct or indirect government funding for the USOPC and the sport governing bodies in return for adherence to more stringent transparency and ethical rules. Ideas that the Commission could consider include mandatory disclosure of information such as sponsorship agreements as well as compensation and bonus limitations for those in key leadership positions, the appointment of an inspector-general, and greater athlete involvement in the U.S. Olympic movement. The article also proposes more statutory changes such as a limited antitrust exemption and the end of special trademark protections for the USOPC.
\end{abstract}

Keywords: United States Olympic and Paralympic Committee, Congress, governance, amateur athletes, antitrust exemption

Mark Conrad, JD, is an associate professor of law and ethics in the Gabelli School of Business at Fordham University. His research interests include sport law, sport governance and ethics, media law, and intellectual property law. Email: conrad@fordham.edu 


\section{Introduction}

The COVID-19 virus, which began in Wuhan, China, at the end of 2019 and spread throughout the world in a few short months, has caused tens of millions of infections, and millions of deaths. ${ }^{1}$ Professional and amateur sports were particularly impacted. Contests ranging from major professional leagues' games to local recreational events have been cancelled or postponed. In the United States, the National Basketball Association ("NBA") and National Hockey League ("NHL") suspended their seasons. ${ }^{2}$ Major League Baseball ("MLB"), which postponed its season for three months, played a truncated schedule of games. ${ }^{3}$ The National Collegiate Athletic Association ("NCAA") cancelled all of its college championships scheduled for the spring of 2020, including the lucrative men's and women's basketball tournaments. ${ }^{4}$ Internationally, the plethora of cancelled or postponed events included many soccer matches, regional and world championships for various sports, various Olympic trials, and, ultimately, the Summer Olympic Games scheduled for Tokyo were postponed, with the quadrennial event slated to take place one year later, in the summer of $2021 .^{5}$

The fallout from the decision by the International Olympic Committee to postpone the 2020 games has affected the various constituent governing bodies in the US. A Wall Street Journal article estimated that the cancellation of the Olympic Games, coupled with the economic damages from COVID-19,

\footnotetext{
1 See Tracking Coronavirus' Global Spread, CNN.com, https://www.cnn.com/interactive/2020/ health/coronavirus-maps-and-cases/ (accessed Nov. 20, 2020). As of mid-November 2020, Authorities in 217 countries and territories have reported about 57.9 million COVID19 cases and 1.4 million deaths since China reported its first cases to the World Health Organization (WHO) in December 2019.

2 See NBA Suspends Season Until Further Notice After Player Tests Positive for the Coronavirus, ESPN.com, March 11, 2020, https://www.espn.com/nba/story//id/28887560/nba-suspends-sea-

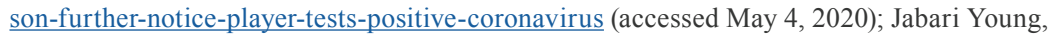
NHL Suspends Season Due to Coronavirus, CNBC.com, March 12, 2020, https://www.cnbc. com/2020/03/12/nhl-to-suspend-season-due-to-coronavirus.html (accessed May 4, 2020).

3 See Tyler Kempner, Baseball's Plan: A Truncated 50-Game Sprint with Fingers Crossed, N.Y. Times, June 23, 2020, https://www.nytimes.com/2020/06/23/sports/baseball/mlb-60-game-season. html (accessed July 12, 2020).

4 See NCAA Cancels Men's and Women's Basketball Championships Due to Coronavirus Concerns, March 17, 2020, https://www.ncaa.com/live-updates/basketball-men/d1/ncaa-cancels-mens-and-womens-basketball-championships-due (accessed May 4, 2020).

5 See, e.g., Coronavirus: How the Virus Has Impacted Sports Events All Over the World, BBC. com, May 4, 2020, https://www.bbc.com/sport/51605235 (accessed May 4, 2020). The lists included the postponement of all soccer Champions League and Europe League tournaments and the first cancelation of Wimbledon "grand slam" tennis tournament since World War II. See also, Kelly Cohen, Tokyo 2020 Olympics Officially Postponed Until 2021, ESPN.com, https://www. espn.com/olympics/story//id/28946033/tokyo-olympics-officially-postponed-2021 (accessed May $4,2020)$.
} 
could result in up to $\$ 800$ million in losses for the United States Olympic and Paralympic Committee ("USOPC") and the national governing bodies ("NGBs") that make up the Olympic system in this country. ${ }^{6}$ It prompted the USOPC to ask Congress for a "handout" of \$200 million, which was denied. The optics of asking for such aid when the virus was spreading throughout the country and resulting in hospitalizations and deaths was, to put it mildly, not ideal. ${ }^{7}$ One commentator said that the entire USOPC board should be "shown the door" for its "tone-deafness and managerial ineptitude" 8

Yet, the very fact that the USOPC (along with a number of $\mathrm{NGBs}^{9}$ needed to run hat in hand to Congress was in large part due to the fact that the US is one of very few countries where Olympic bodies receive no government funding. ${ }^{10}$ In addition, the USOPC (previously known as the United States Olympic Committee until it changed its name in 2019), along with a number of the NGBs like USA Gymnastics, USA Swimming, and USA Track \& Field, have attracted their fair share of criticism and controversy for their less-than-transparent governance, lack of proper action on reports of sexual abuse of athletes (often underage), and general

\footnotetext{
6 See Rachel Bachman, U.S. Olympic Sports Groups Seek Government Aid, The Wall Street Journal, April 12, 2020, https://www.wsj.com/articles/u-s-olympic-sports-groups-seek-government-aid-11586689219 (accessed April 13, 2020).
}

7 This proposal was criticized by some commentators. See Allan Abrahamson, The Challenge is Real . . . Asking Congress for \$200 Million is No Answer, Wire SPORTs, March 26, 2020, (retrieved March 27, 2020) ("why the USOPC had the gumption to say to Congress, in the face of this crisis, that the talents of, say, a backstroker or a rhythmic gymnast or a skateboarder ought to be worth as much or more than the likes of their fellow Americans - truck drivers, janitors, waiters, teachers, salespeople, bartenders, you know, everyday folks."). See also, Will Hobson, USOPC Asked for $\$ 200$ Million in the Coronavirus Stimulus Bill to 'Sustain American Athletes', WAsh. Post, March 26, 2020, https://www.washingtonpost.com/sports/2020/03/26/usopc-asked-200-million-federal-stimulus-money/ (retrieved March 27, 2020) ("In the offices of the senators who received [the] email [from the USOPC], the request was never taken seriously, according to two congressional staffers who spoke on the condition of anonymity to discuss internal deliberations."

${ }^{8}$ See Philip Hersh, U.S. Olympic CEO Deserves Credit for Decision to Take Pay Cut, but She and Board Still Should be Shown the Door, Globetrotting by Philp Hersh, March 27, 2020, http://www. globetrottingbyphiliphersh.com/home/2020/3/27/us-olympic-ceo-deserves-credit-for-decision-totake-pay-cut-but-she-and-board-still-should-be-shown-the-door (retrieved March 27, 2020). ("The time to dissolve the USOPC board - or, at the very least, replace its chairperson - is now.")

9 Id. Among the $18 \mathrm{NGBs}$ - some in non-Olympic sports - who responded to a Globetrotting email survey of 45 such national bodies, 16 said they had applied for PPPs, and 13 said the loans had been approved as of Wednesday. Only three of those 18 have cut or furloughed staff so far, but some have cut salaries and voluntary retirement plan (403b) contributions. Others said salary reductions remain a possibility.

10 See Brian Padden, Olympic Funding Often Reflects Country's Values, Voice of America, Oct. 27, 2009, https://www.voanews.com/archive/olympic-funding-often-reflects-countrys-values (retrieved March 27, 2020). 
spending practices. ${ }^{11}$ Even before COVID-19 struck, the U.S. domestic Olympic movement, starting with the USOPC, was badly in need of governance reform, new business models, greater athlete rights, and more secure methods of funding. Given the economic effects of COVID-19, this need is even more compelling.

As this article will describe in more detail, for too long, the Olympic system suffered from an antiquated structure as a legacy of the Amateur Sports Act, first passed in 1978 and amended two decades later. ${ }^{12}$ While the law was initially successful in centralizing the power of what is now the USOPC, and its relationship with the respective governing bodies of particular sports, the law also resulted in a legacy of flawed leadership of the USOPC and many of the NGBs that make up the main constituents of this system, resulting in a lack of full accountability to the athletes, the U.S. government, and by extension, the American public. These systemic weaknesses flow from the quirky quasi-private, quasi-public system of Olympic governance in the US. The COVID-19 pandemic did not create the underlying problems, but the uncertain financial situation, coupled with the longstanding governance issues, demonstrated how fragile the system is.

The actions (or inactions) of governing bodies such as USA Gymnastics and the USOPC led to pressure by athletes, former athletes, Olympic reformers, and members of Congress to finally amend the ancient law. ${ }^{13}$ Their efforts bore fruit in the fall of 2020 with the passage of the Empowering Olympic, Paralympic and Amateur Athletes Act of 2020. ${ }^{14}$ The law is a positive first step for U.S. Olympic reform. It grants greater Congressional oversight, more athletes' rights, and the

\footnotetext{
${ }_{11}$ Although there are problems with a number of NGBs, USA Gymnastics has fared the worst multiple lawsuits by gymnasts claiming sexual abuse, a bankruptcy filing and a loss of sponsors. [In soccer, See, e.g., Rachel Bachman, U.S. Soccer Federation's Struggles Deepen, Wall StReET JournaL (Dec. 11, 2019) https://www.wsj.com/articles/u-s-soccer-federations-struggles-deep-

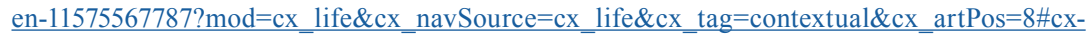
recs_s (retrieved May 1, 2020) (noting that "U.S. Soccer has been operating for more than a year without knowing who its next CEO will be. The brother of the U.S. men's coach, who is the chief commercial officer for the federation, is reported to be a candidate to be the next CEO and in recent years has weighed in on decision-making about soccer staffing usually left to technical experts or coaches, ... “; and "[m] any of U.S. Soccer's youth national team coaches and technical staff have left and haven't been replaced, leaving a void that could have long-term effects on the U.S. men's and women's senior national teams.");]

1292 Stat. 3045 (1978); Pub. L. No. 105-225, 112 Stat. 1253, 36 U.S.C. Sec. 220501 et seq. (1998).

13 See The Committee to Restore Integrity to the USOC; Our Recommendations for an "Athletes First" Olympic Committee, Around the Rings, Jan. 22, 2019), http://aroundtherings.com/ site/A 75538/Title THE-COMMITTEE-TO-RESTORE-INTEGRITY-TO-THE-USOC-OURRECOMMENDATIONS-FOR-AN-ATHLETES-FIRST-OLYMPIC-COMMITTEE/292/Articles (accessed Nov. 15, 2020) ("Our aim with these suggestions is to assure that "Athletes First" is not just a public relations slogan, but that the necessary culture-shift is manifested by embedding it into the structure and governance of the organization.")

14 See S. 2330, 116th Cong. (2020).
} 
creation of a bipartisan commission to study the Olympic system. ${ }^{15}$ While its specific proposals don't radically change the system, it does provide an outlet with the potential to recommend more far-reaching forms - and that is the blue-ribbon panel titled The Commission on the State of U.S. Olympics and Paralympics. This bipartisan panel should do just that.

One major change that should be considered by the commission involves government funding of the Olympic system. For the reasons set forth in this article, the Olympic movement should drop the longstanding policy against government aid. Various models of funding will be explored, including direct appropriations, tax credits, and a community grant system found in funding for arts organizations. In return for the funding, the USOPC and NGBs would be subject to additional governance and transparency requirements, such as: (1) releasing all sponsorship agreements as part of an annual report to Congress and posting these contracts on the organization's website; (2) caps on salaries and bonuses for top employees of the USOPC and NGBs; (3) creating an ethics board wholly independent of the directors of the USOPC and the NGBs; (4) creating a system for great medical insurance coverage for elite athletes; and (5) amending the dispute resolution system and creating an inspector-general to aide in investigating and auditing the operations of the USOPC and the NGBs. Additionally, athletes should be granted the right to assert certain constitutional claims at a time when athletes are seeking the ability to express their political views.

While the USOPC officially expressed support for the reforms found in the 2020 Act, ${ }^{16}$ broader changes, such as government funding, may not be accepted by every stakeholder in the U.S. Olympic system. Detractors will argue that U.S. Olympic sports has been a privately funded affair and that sponsor-based financing, plus contributions from the IOC and broadcaster NBC, has saved U.S. taxpayers money while maintaining impressive medal counts. ${ }^{17}$ These points were well-taken at one time. But with the changed landscape due to COVID-19 and the sex abuse scandals and other governance issues, it is time to change the model.

\footnotetext{
15 See section IV, infra.

16 See Rich Perelman, Lyons Says Olympic World Expects U.S. Leadership; Hirshland Worried about Future of Elite Sport as USOPC Assembly Opens, The Sports Examiner, Oct. 8, 2020, http://www.thesportsexaminer.com/the-big-picture-lyons-says-olympic-world-expects-u-s-leadership-hirshland-worried-about-future-of-elite-sport-as-usopc-assembly-opens/ (accessed Nov. 15,2020 ) ("We worked with the bill sponsors to address concerns, give input, and help ensure that actions recommended and entered into by the legislation would serve the intended purpose. We are satisfied with the collaborative process, and we support this legislation.")

17 See Mike Harrigan, Congress Would Again Reject Plan for USOPC Funding, SpORTs Business Journal, June 15, 2020, https://www.sportsbusinessdaily.com/Journal/Issues/2020/06/15/Opinion/

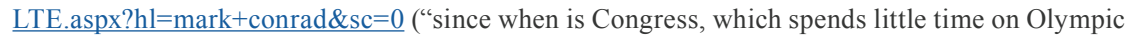
matters, more qualified than the USOPC to regulate USOPC and the NGBs? Let the USOPC do it and report to Congress regularly on results.")
} 
This article will examine the new law and the additional proposed changes in detail. Specifically, it examines: (I) the history of the USOPC before and after the passage of the Sports Act; (II) the present organization and funding of the USOPC and the NGBs; (III) how the law shields the USATF and the NGBs; (IV) the major provisions of the Empowering Olympic, Paralympic, and Amateur Athletes Act of 2020, and the NGBs; and (V) the reforms the Commission on the State of U.S. Olympics and Paralympics should consider in its Report to Congress.

\section{The History of the Olympic Movement in the United States}

\section{A. Before 1978}

The modern Olympic movement was conceived by a French aristocrat, Baron Pierre de Coubertin, who wanted to restage the ancient Olympic games held in ancient Greece over two and a half millennia earlier. ${ }^{18}$ Organized as a finde-siècle celebration of athletic and moral traits and dominated by aristocrats, the Olympics evolved from a relatively small gathering of privileged amateur athletes to a political, cultural, and economic behemoth - an enterprise that has more than 200 national Olympic committees, awards quadrennial winter games that host thousands of athletes, and negotiates multi-billion dollar broadcast contracts that televise the event worldwide. ${ }^{19}$ Since it was formed in 1894, the International Olympic Committee (IOC) has become a powerful non-governmental entity that can operate with virtually unassailable authority in international sports. It has little legal accountability due to its private status and

\footnotetext{
18 See History, Olympic, https://www.olympic.org/ancient-olympic-games/history (accessed March 27, 2020). See also Angela Gemalski, An Olympic Joke: Sanctioning the Olympic Movement, 27 Мich. St. Int'L. L. Rev. 305, 307 (2019).

19 In 2016, the Rio Summer Olympics hosted over 10,000 athletes from 206 countries in over 40 sports. About 7.5 million tickets were available and 380,000 foreign spectators were estimated to attend the games. In addition, 450,000 condoms were distributed to athletes. See Julie In, 16 Facts: Rio 2016 Olympic Games, CNN.com, August 8, 2016, https://www.cnn.com/2016/07/27/ world/16-facts-rio-2016-olympic-games/index.html (accessed May 4, 2020). For the 2018 Winter Olympics in PyeongChang, South Korea, there were 2,952 athletes from 92 countries competing. See 2018 Winter Olympics Facts and Figures, Dean \& Draper Insurance, Feb. 11, 2018, https:// www.deandraper.com/blog/2018-winter-olympic-facts-and-figures (accessed May 4, 2020).
} 
the traditionally hands-off approach of Swiss law. ${ }^{20}$ It preaches goals of peace and harmony through sport through its Charter, ${ }^{21}$ but it has become, as one writer said, "a giant entertainment monopoly." 22 Despite its lofty goals, its history did not display the same sympathy for athlete concerns, as its traditionally autocratic leaders limited rights for athletes engaged in political protest. ${ }^{23}$ The IOC's almost fanatical devotion to amateurism resulted in athletes stripped of their medals for seemingly minor deviations ${ }^{24}$ and for summary enforcement of its rules against

\footnotetext{
20 See Michaël Mrkonjic, The Swiss Regulatory Framework and International Sports Organizations, Danish Institute for Sports Studies, Playthegame.org, https://www.playthegame.org/filead$\mathrm{min} /$ documents/Good_governance reports/AGGIS-report_-12The Swiss regulatory framework p 128-132.pdf (accessed May 9, 2020) ("Until 2000, corruption of foreign public agents was not prosecuted in Switzerland. Offering bribes was the usual way of doing business and they were deductible from corporate tax. ..”) More recently, Swiss lawmakers passed legislation allowing more scrutiny of bank accounts held by governing bodies and their leaders. The law was prompted by FIFA bribery scandals in recent years involving officials from FIFA, the international soccer federation. Presently, the IOC president and other sports officials in Swiss-based bodies are now classed as "politically exposed persons" involved cases of money laundering. See New Swiss Law Allows More Scrutiny of FIFA and IOC Finances, The Guardian, Dec. 14, 2014, https://www. theguardian.com/football/2014/dec/12/swiss-law-fifa-ioc-finances-scrutiny-sports-governing-bodies (accessed May 4, 2020).

${ }_{21}$ See International Olympic Committee [IOC], Olympic Charter, Fundamental Principles of Olympics, https://stillmed.olympic.org/media/Document\%20Library/OlympicOrg/General/ EN-Olympic-Charter.pdf\#_ga=2.14440823.1914180718.1589471959-1158988461.1589471959 (accessed May 14, 2020) ("The goal of Olympism is to place sport at the service of the harmonious development of humankind, with a view to promoting a peaceful society concerned with the preservation of human dignity.")

22 See Brian Alexander, It's Time to Dismantle the U.S. Olympic Committee, Outside the Line, March 2, 2018, https://www.outsideonline.com/2285436/usoc-has-long-way-go (accessed April 3, 2020).

23 See Former IOC President Samaranch Dies, The Wall Street Journal, April 21, 2010, https:// www.wsj.com/articles/SB10001424052748704133804575197713942494370 (accessed June 15, 2020) ("He was also a lightning rod for critics, who attacked him for his ties to the Franco era in Spain, his autocratic style. .."); See also P. S. Wood, Olympics '84, The New York Times, July 3, 1983, https://www.nytimes.com/1983/07/03/magazine/olympics-84.html (accessed June 15, 2020) ("As president of the powerful International Olympic Committee (I.O.C.) from 1952 to 1972, Brundage, a millionaire businessman and athlete, fought what he considered the corruption of the sporting ideal. He sought to strip skiers of their medals if trademarks were visible on their equipment. He found the participation of women in Olympic competition distasteful and resisted their inclusion.")

24 See Sally Jenkins, Why Are Jim Thorpe's Olympic Records Still Not Recognized? Smithsonian, July, 2012, https://www.smithsonianmag.com/history/why-are-jim-thorpes-olympic-records-stillnot-recognized-130986336/ (accessed June 15, 2020) (“Thorpe's epic performance in the 15 events that made up the pentathlon and decathlon at the 1912 Summer Games remains the most solid reflection we have of him. Yet even that has a somewhat shadowy aspect. The International Olympic Committee stripped his medals and struck his marks from the official record after learning that he had violated the rules of amateurism by playing minor-league baseball in 1909-10.”)
} 
political demonstrations. ${ }^{25}$ It also has displayed questionable adherence to ethical standards in the questionable payments to IOC officials by candidate cities to host the games. ${ }^{26}$

The Olympic Charter requires the creation of the National Olympic Committees (NOCs) "to develop, promote and protect the Olympic Movement [with] in their respective countries." ${ }^{27}$ The present USOPC is one of those bodies. In addition, the IOC funds NOC activities, notably in developing nations. ${ }^{28}$

What was known as the United States Olympic Committee traces its origins to the birth of the IOC. The two American members of the original IOC formed a participation committee for U.S. participation in the first modern games in Athens in $1896 .{ }^{29}$ The U.S. Olympic Association (as it was then known) was granted a federal charter in 1950, which gave it nonprofit corporate status, so it could

25 For example, during the 1968 Mexico City games, two U.S. track athletes were expelled and banned from the Olympics under heavy pressure by the IOC See Rick Maese, Two Sprinters Gave the Black-Power Salute at the Olympics. It Took Them Decades to Recover from that Gesture, The Washington Post, May 28, 2018, https://www.washingtonpost.com/national/two-sprintersgave-the-black-power-salute-at-the-olympics-it-took-them-decades-to-recover-from-that-gesture/2018/05/28/b29e9dfc-4a58-11e8-827e-190efaf1f1ee_story.html (accessed June 15, 2020).

26 See Sean Ingle, Tokyo Olympic Games Corruption Claims Brings Scandal Back to the IOC, The Guardian, May 11, 2016, https://www.theguardian.com/sport/2016/may/11/tokyo-olympic-games-2020-ioc-international-olympic-committee-corruption-bid-scandal (accessed May 9, 2020) ("Nagano won the right to host the 1998 Winter Games after providing IOC members with trips to luxury hot spring resorts, first-class air tickets, and geisha ... while the-then IOC president, Juan Antonio Samaranch, was put up in the top suite at the Hotel Kokusai 21, which the Nagano Olympic Committee rented for 30 days at \$2,700 a night. The largesse didn't end there. Nagano also provided millions of dollars in corporate contributions to help build an Olympic museum in Switzerland while the bidding race was going on.... All this was meticulously documented by its bid committee in a series of files that filled 10 large cardboard boxes. However when the focus turned on them, the papers were burned."). In bidding for the 2002 Winter Games in Salt Lake City, 10 IOC members being either expelled or resigning amid allegations of bribes and offers of scholarships, medical care, dubious real estate deals and even sexual favours. Id. However, it should be noted that two members of Salt Lake City Committee were acquitted of conspiracy, mail fraud and wire fraud charges in connection with the bid. See Lex Hemphill, Acquittal Ends Scandal that Dogged Winter Games, N.Y. Times, Dec. 6, 2003, https://www.nytimes. $\underline{\text { com/2003/12/06/sports/olympics-acquittals-end-bid-scandal-that-dogged-winter-games.html }}$ (accessed May 9, 2020).

27 See International Olympic Committee [IOC], Olympic Charter, Ch. 4, sec. 27, Para 1. See also Gemalski, supra at 314 .

${ }_{28}$ See How the IOC Finances a Better World Through Sport, Olympic.org, https://www.olympic. org/funding (accessed July 12, 2020). The IOC represents that $90 \%$ of Olympic Movement revenues are distributed to NOCs, IFs, and OGOCs. Id.

29 The two constituent American members, James Edward Sullivan and William Milligan Sloane, formed a committee to organize the participation of U.S. athletes. See United States Olympic and Paralympic Committee, History, https://www.teamusa.org/About-the-USOPC/History (accessed March 28, 2020). 
solicit tax-deductible contributions. ${ }^{30}$ While the non-profit designation certainly helped in finding private contributors, it also served to get the government out of the governance of Olympic sports. Its name was changed to the more familiar United States Olympic Committee in 1961. ${ }^{31}$

For much its existence, the then-USOC had little input in the selection of Olympic athletes due to conflicts involving more powerful bodies like the Amateur Athletic Union ("AAU") and the NCAA. ${ }^{32}$ By the time of the passage of the 1978 Amateur Sports Act, the law that governs the Olympic sports system in the US, the organizational structure of U.S. Olympic sports was a mess. This was particular acute in track and field where the AAU, founded in $1888,{ }^{33}$ wielded significant power over the sport ${ }^{34}$ and it clashed with the less powerful USOC with regard to the process of choosing an Olympic team. ${ }^{35}$ This resulted in limited

30 Id.

31 Id. In 1940, the AOA changed its name to the United States of America Sports Federation and, in 1945, changed it again to the United States Olympic Association. In 1961, the name was changed to the United States Olympic Committee.

32 See Wood, n. 23 ("In America, by contrast, governance of sport was a crazy quilt of overlapping, aggressively protective or irresponsibly oblivious jurisdictions, controlled mainly by the ever-warring Amateur Athletic Union (A.A.U.) and National Collegiate Athletic Association (N.C.A.A.).")

${ }_{33}$ See About the Amateur Sports Union, aausports.org, https://aausports.org/page.php?page id=99844 (accessed May 14, 2020). ("The AAU was founded in 1888 to establish standards and uniformity in amateur sport. During its early years the AAU served as a leader in international sport representing the U.S. in the international sports federations. The AAU worked closely with the Olympic movement to prepare athletes for the Olympic games. In the late 1970s, the AAU reshifted its focus and efforts to providing sports programs for all participants of all ages beginning at the grassroots level.")

34 Id.

35 See President's Comm'n on Olympic Sports, First Report to the President at 3-5. For further explanation, see Dionne Kohler, A Twenty-First-Century Olympic and Amateur Sports Act, 20 VAND. J. ENT \& TeCh. L. 1027, 1032 (2018). In some cases, high school and college students who "have lost their eligibility to compete in school sports because they have represented the nation in international competition... Athletes have been prevented by the NGB from competing in their sport simply because it was sponsored by a rival organization." See President's Comm'n on Olympic Sports, First Report to the President at 2-3; See also Kohler, supra at 1045. 
corporate support for amateur sports. These organizational problems may have been one reason for the lack of success of the U.S. Olympic teams at a time when the Communist nations, such as the U.S.S.R. and East Germany, were winning a large proportion of Olympic medals. ${ }^{36}$

In 1975, President Gerald Ford appointed a commission to propose changes in the amateur sports system in the US. ${ }^{37}$ Two years later, the commission issued a lengthy report that was highly critical of the structure in place, noting that it was "fragmented, not bound by common purpose or any effective coordinating system." 38 The Presidential commission recommended legislation to create a centralized sport organization that had the exclusive right to select athletes for Olympic Movement competition. ${ }^{39}$ That recommendation would be the cornerstone of what would become the Amateur Sports Act of 1978 (later amended as the Ted Stevens Olympic and Amateur Sports Act). ${ }^{40}$ For purposes of this article, we will refer to both as the Sports Act.

\section{B. 1978-2020}

In a number of ways, the Sports Act successfully standardized a fragmented system. It granted the USOC the "exclusive jurisdiction ... over ... all matters pertaining to United States participation in the Olympic Games ... including representation of the United States in the Games." ${ }^{41}$ It also sought a more aspirational policy role for Olympic athletes and for U.S. athletics in general by establishing national goals for amateur athletics and fostering positive relationships with various athletic organizations. ${ }^{42}$ The law created a new system

\footnotetext{
36 For example, in the 1972 Summer Olympic Games in Munich, the Soviet Union won 50 gold medals to the U.S. count of 33. If one combines East and West Germany, the gold medal is equal to that of the U.S. See 1972 Summer Olympic Medal Table, Wikipedia.org, https://en.wikipedia. org/wiki/1972 Summer Olympics medal table (Accessed January 11, 2020). A major coaching error occurred during those games when the U.S. sprint coach Stan Wright gave the wrong start time for a 100-meter heat because he looked an outdated schedule. The result was that the two runners were disqualified and never ran the race. While coach Wright was subjected to a withering cross-examination on national television by ABC commentator Howard Cosell, USOC officials were not asked to comment. See David Clay Large, MUNICH 1972 - Tragedy, Terror And Triumph at the Olympic Games (Rowman and Littlefield, 2012) p. 184

37 See President's Comm'n on Olympic Sports, First Report to the President 4, 7 (1976). For background, see Neal Amdur, U.S. Report Urges New Body to Direct Amateur Sports, N.Y. TimES, Jan. 13, 1977, p. 54.

38 Id. at n.61.

39 President's Comm'n on Olympic Sports, First Report to the President at xix.

40 P.L. 95-606 (codified at 36 U.S.C. $\$ 371$ et seq. (1978)).

41 See Gold Medal LLC v. USATF, 187 F.Supp.3d 1219, 1228 (D. Oregon 2016), citing 36 U.S.C. § 220503(3) (2012).

42 See 36 U.S.C. $§ 220503$.
} 
of dispute resolution procedures ${ }^{43}$ and sought to provide opportunities to develop programs for women, minorities, and disabled athletes. ${ }^{44}$

In return for its exclusive jurisdiction to control U.S. Olympic participation, the now-USOPC is required to designate a respective national governing body in a sport to establish criteria to select athletes in its given sport. ${ }^{45}$ The chosen NGBs run and oversee their sport or group of sports, and establishes criteria for competition and sanctioning competitions on a regional and national level, ${ }^{46}$ recommending to the USOPC the athletes and teams suitable to represent the US in the Olympic Games, the Paralympic Games, the Pan-American Games, and other international competitions. ${ }^{47}$ It also allows the 47 national governing bodies to fund their own operations, essentially from sponsorship agreements. ${ }^{48}$ The NGBs also receive funding by the USOPC, which came to $\$ 65$ million in $2018 .{ }^{49}$ Part of the problem derives from rules made by the USOPC, which require CEOs to be paid and appointed while board positions are to be voluntary. ${ }^{50}$

In 1998, the Sports Act was amended to include provisions involving the inclusion of Paralympic athletes to the then-USOC's jurisdiction and essentially replicated the same system for those athletes. ${ }^{51}$ It also increased (at least in theory) athletic participation in decision making by the then-USOC and the NGBs by creating "athletes advisory councils" for the then-USOC and the NGBs. ${ }^{52}$ The amendments required that $20 \%$ of the USOC board compromise amateur athletes. ${ }^{53}$ In addition, the then-USOC was required to hire an "athlete ombudsman" to advise athletes on their rights in disputes with governing bodies. The USOC was also given additional authority, including the ability to move to federal court any suit brought in state court for violation of the Sports Act, ${ }^{54}$ and a provision was introduced preventing a court from entering injunctive relief against the USOC in any dispute over an athlete's participation in the Olympic Games where

\footnotetext{
$43 \quad I d$.

44 Id.

45 Id. at $\S 220505(\mathrm{c})(4)$.

$46 I d$. at $\S 220523(\mathrm{a})(2)-(4)$.

47 Id. at $\S 220523(\mathrm{a})(6)-(7)$. For a more thorough explanation, see Kohler, n. 33 supra at 1049-50.

$48 \quad I d$. at $\S 220524$

49 See Money Crisis Faces U.S. Olympic Sports, Tampa Bay Times, March 20, 2020, https://www. tampabay.com/news/health/2020/03/28/money-crisis-faces-us-olympic-sports/ (accessed May 14, 2020).

$50 \quad I d$. at 220523(a)

${ }_{51}$ See Olympic and Amateur Sports Act Amendments of 1998, Pub. L. 105-277, (Oct. 21, 1998)

112 Stat. $2681-603$.

52 Id. See also Kohler, n. 33 at 1051.

53 See USOPC Bylaws, § 3 (2017)

5436 U.S.C. § 220505(b)(9).
} 
the claim is brought within 21 days of the event. ${ }^{55}$ Finally, the 1998 amendments eliminated private rights of action against the USOC and the NGBs,${ }^{56}$ a point that will be discussed in more detail later in this article.

This legislative blueprint gave the then-USOC a peculiar status. Despite its federal charter, it is not a governmental entity and was not subject to frequent oversight by Congress. Under the original Sports Act, its duty was to submit a quadrennial report to Congress ${ }^{57}$ As one scholar put it, a Federal charter is more an "honorific" and it confers no substantive relationship with the federal government. ${ }^{58}$ More recently, however, the USOPC has been the subject of investigation by the Senate and House committees as a result of abuse scandal at USA Gymnastics. ${ }^{59}$ Yet despite these recent initiatives, the oversight of the USOPC generally has been haphazard. ${ }^{60}$

\section{Present Organization and Funding of the USOPC and the NGBs}

\section{A. Structure}

As of 2020, the United States Olympic \& Paralympic Committee (renamed in 2019) is governed by a 16 -member board of directors, headed by a CEO, that meets four times per year. The powers of the USOPC board are standard for a

\footnotetext{
${ }_{55} I d$.

$56 \quad I d$.

5736 U.S.C. $\$ 220511$ (2018).

58 See Dionne Kohler, Amateur Regulation and the Unmoored United States Olympic and Paralympic Committee, 9 WaKe Forest L. Rev. Online 88 (Nov. 2019), http://wakeforestlawreview.com/2019/11/amateur-regulation-and-the-unmoored-united-states-olympic-and-paralympic-committee/\# ftn33 (accessed May 17, 2020).

59 See Juliet Macur, Congress Holds Hearings into Sexual Abuse in Olympic Sports, N.Y. Times, May 23, 2018, https://www.nytimes.com/2018/05/23/sports/larry-nassar-house-hearing.html (accessed May 18, 2020) (Heads of the USOC, USA Gymnastics, USA Swimming, USA Taekwondo, and USA Volleyball testified to a House subcommittee investigating how the Nassar scandal happened and determining what the USOC and the governing bodies are doing to prevent future abuse.)

60 See Kohler, n. 57, supra.
} 
non-profit entity. ${ }^{61}$ The board includes six "independent members" (also known as "independent directors"), three members from the NGBs, and three members nominated by the Athletes Advisory Council. ${ }^{62}$ An independent board member cannot have held a paid or volunteer governance position at the USOPC or an NGB from a two-year period to appointment. ${ }^{63}$ The CEO of the organization and all the American members of the IOC are ex officio members of the board. ${ }^{64}$

The board utilizes what are known as "constituent councils" to "serve as sources of opinion and advice" to the board. ${ }^{65}$ Two of them, the Athletes' Advi-

\footnotetext{
${ }^{61}$ Board members are empowered "to take such other action as is customary for a board of directors of a corporation," including the appointment of a CEO, setting compensation for the CEO and key employees, engaging in strategic planning and budgeting. See Bylaws of the United States Olympic Committee, $\$ 3.1$ (2018). Other duties include:
}

a)to elect members of the Board, following receipt of the recommendations of the Nominating and Governance Committee and to elect the Chair;

b) to remove the Chair or any other member of the Board or any Committee for cause or not for cause;

c) to elect one member of the Board to act as, and be referred to internationally as, the President of the U.S. Paralympics;

d) to hire, fire, evaluate and set the compensation for the CEO;

e) to enact, amend, or repeal provisions of these Bylaws;

f) to admit new members, to reclassify and to terminate the membership of members, as provided by these Bylaws;

g) to receive and review the reports of the CEO and committees and task forces;

h) to approve the selection of independent auditors;

i) to maintain a culture of ethical behavior and compliance throughout the corporation;

j) to achieve as much transparency in the operations of the corporation as is reasonably achievable and to keep the attendees at the Olympic and Paralympic Assembly and the stakeholders in the Olympic and Paralympic movements in the United States informed about the business and operations of the corporation; and

k) to take such other action as is customary for a board of directors of a corporation.

62 Id.

${ }_{63}$ Id. at 3.4. In addition, the two-year period applies where an immediate family member of the director was employed by or held any paid position or volunteer governance position with the USOPC or NGBs; the director was affiliated with or employed by the corporation's outside auditor or outside counsel; an immediate family member of the director was affiliated with or employed by the corporation's outside auditor or outside counsel as a partner, principal, or manager; or the director held a paid position or any volunteer governance or leadership position with, the AAC.

${ }^{64}$ See Bylaws of the USOC Athletes Advisory Council, Art 3(d) (2018), usocdev.org, (accessed May 14, 2020). They are the Athletes' Advisory Council, National Governing Bodies Council, Multi-Sport Organizations Council, the Paralympic Advisory Committee, and Collegiate Advisory Council.

${ }_{65}$ See United States Olympic and Paralympic Committee 2018 Annual Report, p. 6, https://www. teamusa.org/footer/finance (accessed April 11, 2020). 
sory Council and National Governing Bodies Council, each have three representatives on the board, while six members of the board are "independent." It also has a number of committees, which include an Ethics committee of five members appointed by the board. ${ }^{66}$

The Athletes' Advisory Council ("AAC") is responsible for broadening communication between the USOPC and active athletes, and serves as a source of input and advice to the organization's board of directors. ${ }^{67}$ It is comprised of one representative from each Olympic and Pan American sport, eight athletes representing the Paralympic Sport Organizations, and six athletes elected by the AAC to serve at-large, including a chair and two vice chairs. Athletes on the AAC must have represented the U.S. in Olympic, Paralympic, Pan American, or other major international competition within the last 10 years. ${ }^{68}$

There has been criticism that the AAC has not been an effective voice for athletes' concerns ${ }^{69}$ and some athletes considered breaking away and forming an independent organization to represent their concerns. However, an agreement entered in early 2020 ensures that the AAC will stay under the wing of the organization in return for more funding and the appointment of a full-time executive director. ${ }^{70}$ As one AAC representative stated, "a lot of athletes weren't really comfortable taking the risk of creating a completely independent organization." "71

As noted earlier, the 1998 Amendments to the Sports Act require the USOPC to appoint an "athlete ombudsman" to provide independent advice to athletes, at no cost, "in resolving disputes involving opportunities for athletes to participate

\footnotetext{
66 See United States Olympic and Paralympic Committee, 2020 Bylaws, sec. 5.5.1. https://www. teamusa.org/Footer/Legal/Governance-Documents. The other committees are Finance, Audit, and Risk; and Nominating and Governance.

${ }^{67}$ Id. See also United States Olympic and Paralympic Committee/Leadership/AAC, https://www. teamusa.org/About-the-USOPC/Leadership/AAC (retrieved March 29, 2020).

68 Id.

69 See Tom Roeder and Stephanie Earls, USOC Leaders, Athletes and Critics Cite Communication Breakdown, The GAZETTE (Colorado Springs), Jan. 13, 2019, https://gazette.com/news/ usoc-leaders-athletes-and-critics-cite-communication-breakdown/article fe4858b0-15f0-11e9a62e-57101a784c5a.html (accessed May 29, 2020). (Some athlete representatives were "seen by some critics and athletes as being allies of the old regime of Olympic Committee.")

70 See Rachel Bachman, Athletes Reach Deal to Gain Funding but Stay Under U.S. Olympic Wing, The Wall Street Journal, Jan. 23, 2020, https://www.wsj.com/articles/athletes-reach-dealto-gain-funding-but-stay-under-u-s-olympic-wing-11579813012 (accessed March 29, 2020). The agreement would triple the governing body's annual funding of the athlete group, to $\$ 525,000$. The funding increase will enable the AAC, which for decades has been led by athlete volunteers, to hire a professional executive director.

${ }^{71} I d$. (Statement by AAC chair Han Xiao).
} 
in Olympic, Paralympic, and Pan American Games; world championship competitions; or other protected competitions." 72

Because Congress does not provide funding for Olympic sports, the Sports Act gave the then-USOC the authority to do so. ${ }^{73}$ To help in its quest for financial stability, the Sports Act awarded it the rights to control their trademarks, including the word "Olympics" and the five-ring logo. The protections and enforcement are broader than for most other trademarks ${ }^{74}$ and differ from the protection under the Lanham Act, the general governing law for trademarks. ${ }^{75}$ The Lanham Act requires that the unauthorized use of a trademark in commerce must show a "likelihood of confusion," 76 while the Sports Act states that the unauthorized use of an Olympic trademark is actionable without the need to prove such confusion. ${ }^{77}$ In addition, the Supreme Court has ruled that an unauthorized user of the word "Olympics" does not have available the normal statutory defenses. ${ }^{78}$ Under the Sports Act, the NGBs own the rights to the trademarks for their given sport. ${ }^{79}$

The USOPC also provides cash grants to the NGBs. In 2018, it amounted to $\$ 65$ million. ${ }^{80}$ This is an important source because, as one report stated, "half the NGBs are little more than ma-and-pop operations, working with small staffs

\footnotetext{
72 See USOPC Athlete Ombudsman, https://www.usada.org/athletes/usopc-athlete-ombudsman/ (accessed April 19, 2020).

73 See 36 U.S.C. $§ 220521(a)$,

74 See 36 U.S.C. $\$ 380$. Among the protected marks are "OLYMPIC, OLYMPIAD, OLYMPIAN and FUTURE OLYMPIAN; GO FOR THE GOLD and GATEWAY TO GOLD, LET THE GAMES BEGIN, PARALYMPIC, PARALYMPIAD and PARALYMPIAN and PAN-AMERICAN, PAN AM GAMES. See U.S. Olympic and Paralympic Brand Usage Guidelines, https:// www.teamusa.org/brand-usage-guidelines (accessed May 14, 2020). In order to protect that income stream, Congress also conferred enhanced authority upon the USOC, granting it rights that, in certain circumstances, exceeded those then enjoyed by most trademark owners, and enhanced enforcement powers. See S.F. Arts \& Athletics, Inc. v. U.S. Olympic Comm., 483 U.S. 522, 523 (1987); see also, Marcella David, Trademark Unraveled: The U.S. Olympic Committee Versus Knitters of the World, 14 Minn. J. L. Sci. \& ТЕсн. 705, 715 (2013).

75 See Lanham Act, 15 U.S.C. § 1051 et. Seq.

76 Id. at $1125(\mathrm{a})$.

77 See 36 U.S.C. $§ 220506$ (c).

78 See S.F. Arts \& Athletics, Inc., 483 U.S. at 530. For a detailed discussion on the ambiguities between trademark protection under the Lanham Act and the Sports Act, see Marcella David, Trademark Unraveled: The U.S. Olympic Committee Versus Knitters of the World, 14 MinN. J. LAW, SCIENCE \& TECH. 705 (2013).

79 See U.S. Olympic and Paralympic Brand Usage Guidelines, https://www.teamusa.org/ brand-usage-guidelines (accessed July 14, 2020).

80 See Eddie Pells, No Games, Big Losses: Money Crisis Faces US Olympic Sports, AssociatED Press, March 27, 2020, https://apnews.com/82241fb79bcbabe42d27b4e2160a8d85 (accessed March 28, 2020).
} 
and on revenue not more than $\$ 5$ million a year." 81 Among the organizations receiving grants in 2018 were USA Hockey, USA Judo, USA Karate, and nonNGB organizations like National Wheelchair Basketball. ${ }^{82}$ However, some of the grantees were not mom-and-pop operations. USA Track \& Field received almost $\$ 4$ million that year, despite its endorsement agreement with Nike valued in the hundreds of millions of dollars. ${ }^{83}$

Before the COVID-19 crisis, the USOPC employed about 500 people and had a budget of approximately $\$ 1$ billion over two years. ${ }^{84}$ According to the USOPC, the organization spent about $83 \%$ of its budget supporting athletes, another $10 \%$ on fundraising costs, and the rest on administrative expenses. ${ }^{85}$ Nearly half of the USOPC's budget is directed toward programming and services that support and impact elite performance for Olympic and Paralympic athletes and hopefuls either directly or via the appropriate national governing body. ${ }^{86}$ Considerably smaller sums go to Olympic and Paralympic competitions, ${ }^{87}$ training facilities (in Colorado Springs, CO, and Lake Placid, NY), ${ }^{88}$ the NGBs, the U.S. Anti-doping Agency, and the U.S. Center for SafeSport. ${ }^{89}$ The proceeds to SafeSport have received much criticism as being too paltry and the 2020 law significantly increases the amount. ${ }^{90}$ The USOPC gives financial support to a number of elite athletes often from private donors through its foundation. It also provides health insurance to more than 1,000 athletes.

\footnotetext{
$81 \quad I d$.

82 See United States Olympic Committee, 2018 Form 990 tax return, schedule I. https://www. teamusa.org/footer/finance (accessed April 12, 2020).

83 Id.

${ }^{84}$ See Philip Hersh, For Many Olympic-Related Sports Bodies in the USA, Surviving Fiscal Impact of Pandemic Would Be Like Winning a Gold, Globetrotting by Philp Hersh, April 29, 2020, http://www.globetrottingbyphiliphersh.com/home/2020/4/29/for-many-olympic-related-sportsbodies-in-the-usa-surviving-fiscal-impact-of-pandemic-would-be-like-winning-a-gold (accessed April 30, 2020).

${ }^{85}$ See USOPC, Allocation of Resources, https://www.teamusa.org/About-the-USOPC/Allocation-of-Resources (accessed March 29, 2020).

86 Id. ("In addition to grants and rewards that pay for coaches, training and travel, this includes athlete health insurance, sports medicine and science, coaching education programs, and Paralympic outreach and development. In 2020, that amount to over $\$ 440$ million or 47 percent of the budget.").

${ }^{87} I d$. The amount for 2020 was over $\$ 85$ million or $8 \%$ of the budget.

88 Id. The amount for 2020 was $\$ 112$ million or $11 \%$ of the budget.

${ }^{89}$ Id. The amount for 2020 was $\$ 118$ million or $12 \%$ of the budget.

90 Id. The amount allocated to SafeSport was only \$18.6 million. See also 36 USC 220541(g) (requires USOPC to pay \$20 million to the USA Center for SafeSport )
} 
In 2018, the USOPC had assets of $\$ 468$ million and liabilities of $\$ 126$ million. ${ }^{91}$ The sources of revenue centered on broadcast and sponsorship and licensing fees. ${ }^{92}$ The USOPC's activities are organized within a four-year cycle ending in the year the Olympic Games are held. The postponement of the Summer 2020 Olympic games, consequently, had ramifications for 2020 revenues as the games were deferred to at least $2021 .{ }^{33}$ There are also revenues deriving from donations ${ }^{94}$ Broadcast rights income is significant, because of the lucrative agreement between NBC and the IOC for the broadcast of the Summer and Winter Olympic Games to U.S. audiences. The 2018 statement reports that the USOPC will receive $12.75 \%$ of the $\$ 7.65$ billion that NBC will pay for the Olympics from 2022 to 2032. In addition, NBC has a separate broadcasting agreement with the USOPC for rights to broadcast various Olympic trials for $\$ 60$ million over that same 10 -year period. ${ }^{95}$ However, a separate revenue-sharing agreement with the IOC mandates that the USOPC pay back money to the IOC to offset the costs of the Olympic Games (even if they were not in the US). The amounts paid were $\$ 15$ million for the 2012, 2016, 2020 periods. That increases to $\$ 20$ million starting in $2021 .{ }^{96}$ The report also outlines the various investments that the USOPC made. ${ }^{97}$

The coronavirus pandemic and the resulting postponement of the Tokyo 2020 Summer Games until the summer of 2021 (assuming that the games will be held) created financial uncertainty for a considerable number of U.S. Olympic and Paralympic athletes who already have qualified for those Games, or were seeking to so qualify. As one commentator noted, with the delay in money from television revenues and any possible alteration of the terms of the sponsorship

\footnotetext{
91 See 2018 Consolidated Financial Statements and Report of Independent Certified Public Accountants, United States Olympic Committee, p. 5., https://www.teamusa.org/footer/finance (accessed April 11, 2020).

${ }_{92} I d$. at p. 6. In 2018, Sponsorship and licensing came to almost $\$ 145$ million and broadcast revenue was over $\$ 121$ million.

93 Id. at p. 12. Because of the Olympic calendar, the consolidated financial statements include the changes in net assets and cash flows for the year ended Dec. 31, 2018, and the two-year period ended Dec. 31, 2018, the second year of the four-year cycle. However, I only used figures for 2018, and did not include 2017.

$94 \quad I d$.

95 Id. at p. 29, note J.

96 Id. at p. 31, note M. The USOPC makes periodic contributions to the IOC to offset the costs of the Olympic Games and Olympic Winter Games held through 2040. Under the agreement, the then-USOC made quarterly payable totaling $\$ 45,000,000$ to the IOC for the 2012,2016 , and 2020 quadrennial periods. Beginning in 2021 and ending in 2040, the USOPC will contribute $\$ 20,000,000$ to the IOC during each quadrennial period, adjusted for inflation as defined in the agreement. However, with the postponement of the 2020 Tokyo Olympics, the amount for 2021 may be amended. It is unclear at this time.

${ }_{97}$ Id. at p. 24 (Note D -- Disclosures about fair value of assets and liabilities).
} 
agreements due to the delay, the USOPC may be in a more precarious position than Olympic committees from other countries, which have governmental funding. ${ }^{98}$ In fact, the postponement resulted in likely USOPC budget cuts of $10-20 \%$ annually until 2024. As of 2020, the USOPC's share of the domestic broadcast fees from NBC Universal ("NBCU") would have been about \$185 million, a significant portion of the organization's projected revenue of $\$ 412$ million. ${ }^{99}$ As a result, the USOPC announced buyouts, ${ }^{100}$ layoffs, and furloughs. ${ }^{101}$

Aside from television revenues, an important source of USOPC funding comes from the sale of domestic and international sponsorships. In light of the Summer Olympics delay, the USOPC proposed to extend current sponsorship agreements for one more year, but that may result in a conflict between old sponsors and new ones which may be competitors of the expiring sponsors and which were to begin in $2021 .^{102}$

As of the fall of 2020, it is not yet known what concessions sponsors will seek because of the delay of the Olympics. However, it is likely that any extensions of existing agreements and/or delays in payments will further weaken the financial position of the USOPC. This situation could lead to one of two results: either the training of athletes will be curtailed or the USOPC will obtain "bailout" money

\footnotetext{
98 See Ron Katz, US Gov't Should Replace US Olympic Committee, Law360, April 10, 2020, https://www.law360.com/sports-and-betting/articles/1261478/us-gov-t-should-replace-us-olympiccommittee?nl_pk=6ada3079-4db3-4c29-8042-be5ea277a863\&utm_source=newsletter\&utm medium=email\&utm_campaign=sports-and-betting (accessed April 13, 2020).

99 See Rachel Bachman, Coronavirus Prompts Budget Cut for U.S. Olympic \& Paralympic Committee, The Wall Street Journal, April 21, 2020, https://www.wsj.com/articles/coronavirusfallout-prompts-u-s-olympic-paralympic-committee-to-cut-budget-10-20-11587492104 (accessed April 21, 2020). Because of the USOPC operates in four-year cycles, the projected revenue for that period would have $\$ 1.12$ billion and the delay may force the USOPC to cut its estimate by $\$ 200$ million. Id.
}

100 See Chris Smith, USOPC Begins Cost-Saving Efforts; 30-Plus Employees Take Buyouts, Sports Business Daily, May 7, 2020, https://www.sportsbusinessdaily.com/Daily/ Issues/2020/05/07/Olympics/USOPC.aspx?ana $=m k$ sbd_da_emda\&mkt tok=eyJpIjoiWmpWbE1qSTRORFEyWVRrMiIsInQiOiJ3TktVekpyVDVMa2JZb2RxODAyYWxTNjRuS251UHRQW1V2b1BuSUp3bTlwU1NuM1JZM0xRT11WUXNMR2oyelZVVVN5NktZUFk2dXRXekxJYjh5Rk55ejArXC9IOHVYendjVGdGUEpOdnNldEJuTHA2TkxhMnFKOVkyYUNNSHEwRUMifQ\%3D\%3D (accessed May 7, 2020).

101 See Bob Williams, USOPC implements widespread layoffs and furloughs in cost-cutting measure, SportBusiness, May 22, 2020, https://www.sportbusiness.com/news/usopc-implementswidespread-layoffs-and-furloughs-in-cost-cutting-measure/ (accessed May 29, 2020).

102 Chris Smith, USOPC Offers to Extend Domestic Sponsorships to 2021, SporTs BusiNESS DAILY, April 16, 2020, https://www.sportsbusinessdaily.com/Daily/Closing-Bell. aspx?ana $=m k$ sbd_cb_emcb\&mkt tok=eyJpIjoiTVRFeU56QTNOM1JoTm1NeSIsInQiOiJzS2VvaTFmdTd2KzV6ZDlyZ2RwWEFUUnczcmJibX1rRDdRS3pYUFVaRzA0ck5FY1N3c1JWM1hOVXZnS094RG5vTEIEZW51TmFoRINOSWJFZzIrM1RsYW8zRVFuZ3NFdEVyMmN6Z0JHMnJyVHNzcVZPVERQWk1NbHBMUnIrblwvTnkifQ\%3D\%3D (accessed April 16, 2020). 
from the U.S. government. Government aid is not likely because, as noted at the beginning of this article, the USOPC sought $\$ 200$ million, but that request was rejected. $^{103}$

If the Tokyo games are cancelled outright, the situation could become even more dire. One report said that the USOPC opted not to take out insurance against such losses, but rather to self-insure. ${ }^{104}$ And with the likely loss of broadcast fees, the finances of both the USOPC and the NGBs would be seriously strained. There would also be a likelihood of decreases in membership among the NGBs (and the resulting loss of dues revenues). ${ }^{105}$

Over two-thirds of the U.S. NGBs did request emergency funding from the federal Paycheck Protection Program ("PPP") in 2020 and about \$13 million in funds was approved. The largest amount was over \$2.5 million to USA Skiing; the smallest was $\$ 75,000$ to USA Badminton. ${ }^{106}$

\section{B. Ethical and Transparency Weaknesses}

Almost from the beginning of the Sports Act era, the then-USOC was beset with organizational, financial, and ethical lapses. In the 1990s, the USOC was led by five different CEOs in six years. In addition, two of its medical directors accused the organization of covering up positive drug tests and of creating an atmosphere that encourages the use of performance-enhancing drugs. ${ }^{107}$ It also was accused of a lack of oversight during Salt Lake City's scandal-plagued bid to win the

\footnotetext{
103 See n. 7, supra.

104 See No Games, Big Losses: Money Crisis Faces US Olympic Sports, The Economic Times, March 28, 2020, https://economictimes.indiatimes.com/news/sports/no-games-big-losses-moneycrisis-faces-us-olympic-sports/articleshow/74857858.cms?utm_source $=$ contentofinterest\&utm medium=text\&utm_campaign=cppst (accessed June 20, 2020).
}

105 See Louise Radnofsky and Rachel Bachman, U.S. Olympic Sports Bodies Could Lose $\$ 800$ Million Over Coronavirus, Olympics Delay, The Wall Street Journal, March 26, 2020, https:// www.wsj.com/articles/u-s-olympic-amateur-sports-bodies-could-lose-800-million-over-coronavirus-and-olympics-delay-11585226701 (accessed Nov. 15, 2020) (“[Olympic] Postponement introduces an entirely different fiscal picture for us that is not yet clear.")

106 See Eddie Pells, AP Exclusive: 70\% of US Olympic Sports Applied for PPP Funds, Associated Press, May 8, 2020, https://apnews.com/article/6d28d5af9c8151b82668609a0f45d5dd (accessed Nov. 15, 2020)

107 See Jere Longman, OLYMPICS; U.S.O.C.'s Struggles Threaten United States Olympic Movement, N.Y. Times, Nov. 26, 2000, https://www.nytimes.com/2000/11/26/sports/olympicsusoc-s-struggles-threaten-united-states-olympic-movement.html (accessed April 21, 2020). (“The drug-testing program has become so discredited that in October, the U.S.O.C. farmed out its testing program to an independent agency headed by Frank Shorter, the 1972 Olympic marathon champion.") 
2002 Winter Games. ${ }^{108}$ Internally, the USOC had an unwieldy volunteer board of 115 members representing various governing bodies and other constituencies that bickered over petty matters and at its worst moments, engaged in open conflict with its paid leadership. One CEO, upon his resignation, said "this was a far more political organization than I could have possibly imagined. I wonder whether the organization has the resolve or the fortitude to recreate itself." 109 That same CEO, however, was criticized by the USOC's vice-president after he hired several staff members at $\$ 300,000$ or more a year and provided lucrative packages, including guaranteed bonuses and $\$ 70,000$ to $\$ 90,000$ in moving costs (in late 1990s dollars). ${ }^{110}$ Ultimately, the USOC did reduce the number of board members, which eased some of the organizational problems. ${ }^{111}$

More recently, however, the then-USOC's lack of action in the sexual abuse scandals on hundreds of young female gymnasts brought national criticism. ${ }^{112}$ For example, after damning press accounts of USA Gymnastics shielding the abuses by Dr. Larry Nassar, ${ }^{113}$ an independent investigation revealed that the USOC did not report Nassar to law enforcement or take any steps to bar Nassar from USOC events or facilities. The report added that the USOC did not even discuss the allegations against Nassar with its own department that deals with

\footnotetext{
108 Id. A panel lead by a former U.S. Senator noted "[USOC] officials attended few meetings to monitor the activities of bidders. That allowed the committee's former head of international relations, Alfredo LaMont, to work secretly as a paid consultant with Salt Lake City bidders. LaMont subsequent plead guilty to tax-related charges in the scandal."

109 Id. (Statement of former USOC CEO Norm Blake after his resignation). Examples of the petty bickering included such issues as whether staff members should be entitled to the same leather jackets and rings as the Olympic athletes.

110 Id. Sandy Baldwin, a USOC vice president, sent a letter to Bill Hybl, the committee's outgoing president, raising concerns about the proposed budget and salary levels.

111 See Scott M. Reid, USOC Signals Push for More Control Over All Governing Bodies for Olympic Sports, The Oregonian, Dec. 6, 2018, https://www.ocregister.com/2018/12/06/usocsignals-push-for-more-control-over-all-governing-bodies-for-olympic-sports/ (accessed July 20, 2020) ("The USOC reduced its board of directors from 120 to 11 in 2003. It expanded its board to 15 members in 2010.").

112 See Will Hobson, USOC, USA Gymnastics Did Not Protect Athletes After Larry Nassar Complaints, Report Shows, The Washington Post, Dec. 10, 2018, https://www.washingtonpost. com/sports/olympics/usoc-usa-gymnastics-did-not-protect-athletes-from-larry-nassar-reportshows/2018/12/10/5f3fc2fa-fcb7-11e8-862a-b6a6f3ce8199 story.html (accessed Nov. 15, 2020), (“As criticism of the USOC over the Nassar scandal reached a crescendo earlier this year - shortly after the wrenching testimony of more than 150 accusers during Nassar's sentencing hearing ignited national outrage in January — USOC board members publicly voiced support for [its then CEO].")

113 See Marisa Kwiatkowski, Mark Alesia and Tim Evans, A Blind Eye to Sex Abuse: How USA Gymnastics Failed to Report Sex Abuse, The Indianapolis Star, Aug. 4, 2016, https://www. indystar.com/story/news/investigations/2016/08/04/usa-gymnastics-sex-abuse-protected-coaches/85829732/ (accessed May 15, 2020).
} 
sexual abuse cases. ${ }^{114}$ The problem and lack of action on sexual abuse existed well before the Nassar scandal, dating back two decades and involving other NGBs. The USOC and the respective NGBs' failure to act to prevent this conduct was nothing short of astounding. Abuses not only incurred in gymnastics, but also in swimming ${ }^{115}$ and other sports over many decades. ${ }^{116}$ Then USOC CEO Scott Blackmun was asked to resign in 2018, receiving a controversial severance package totaling \$2.4 million. ${ }^{117}$ As a sign that the USOPC and the NGBs could not be entrusted to protect athletes, the Safe Sport Authorization Act enacted in 2017 mandated criminal penalties for the failure to report suspected sexual abuse. ${ }^{118}$ In 2019, the USOC and its leadership accepted the need for reform in the

114 See Ropes \& Gray, Report of the Independent Investigation - The Constellation of Factors Underlying Larry Nasser's Abuse of Athletes, https://www.nassarinvestigation.com/en (accessed May 15, 2020). See also, Juliet Macur, Top U.S.O.C. Officials Failed to Act on Nassar Allegations, Report Says, N.Y. Times, Dec. 10, 2018), https:/www.nytimes.com/2018/12/10/sports/usoc-investigation-report.html (accessed May 15, 2020).

115 See Letter by the Committee to Restore Integrity to the USOC (Robert Allard, Jessica Armstrong, Kathy Johnson Clarke, Nancy Hogshead-Makar, Micki King, Jonathon Little, Eva Rodansky, Patricia A. Rodowsky, Jennifer Sey, Jennifer Spiegel, Edward G. Williams, The USOC Knew NGBs were not Complying with the Amateur Sports Act, Knew Athlete Sexual Abuse was a Frequent, Reoccurring Problem, and Made the Calculated Decision not to Act on Behalf of Athletes, Feb. 4, 2018), https://swimmingworld.azureedge.net/news/wp-content/uploads/2018/02/ usoc-memo-congress-blackmun.pdf (one particularly outrageous example cited: "The USOC and USA Swimming fail[ed] to take action against Olympian and USA Swimming-certified swim coach Mitch Ivey, even though he [was] fired from the University of Florida after The Chicago Tribune, N.Y. Times and ESPN Outside the Lines report on Ivey's sexual abuse of numerous underage athletes. One of Ivey's victims commit[ed] suicide years later. An investigation of Ivey during his tenure at the Santa Clara International Swim Club in the 1980s would have found rampant problems of sexual abuse, not only by Ivey, but also by Ivey's assistant coaches. USA Swimming waited 20 years to ban Mitch Ivey, allowing him to sexually harass and abuse other young swimmers.")

116 See Senators Jerry Moran and Richard Blumenthal, Senate Olympics Investigation: The Courage of Survivors: A call to Action, July 30, 2019, https://www.moran.senate.gov/public/ cache/ files/c/2/c232725e-b717-4ec8-913e-845ffe0837e6/FCC5DFDE2005A2EACF5A9A25FF76D538 2019.07.30-the-courage-of-survivors--a-call-to-action-olympics-investigation-report-final.pdf (accessed July 5, 2020). ("While the Nassar case is breathtaking in scale, athletes from a range of Olympic sports have similarly suffered abuse at the hands of officials, coaches, fellow athletes, and others connected to their sports. The egregious nature of this and past instances of abusecombined with the number of victims - required Congressional attention and action.")

117 See Jere Longman, U.S. Olympics Chief Received \$2.4 Million in Severance Amid Scandal, N.Y. Times, July 3, 2019, https://www.nytimes.com/2019/07/03/sports/olympics-scott-blackmun.

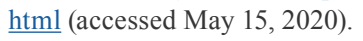

118 See Safe Sport Authorization Act of 2017, Public Law 115-126, 132 Stat. 318 (Feb. 2017) 
operations of the organization. ${ }^{119}$ Also that year, the organization was formally renamed the USOPC to recognize the contributions of Paralympians. ${ }^{120}$

\section{Financing}

For many NGBs, their finances are heavily dependent on their own sponsorship agreements and, secondarily, aid from the USOPC. While the amounts and percentages vary from year to year and group to group, generally, NGBs receive less than $10 \%$ of their annual revenues from the USOPC. ${ }^{121}$ Some also receive support from international sports federations. ${ }^{122}$ NGBs are also dependent on membership and event registration fees for revenue. Unfortunately, they have seen membership fees and event revenues drop or vanish as precautions to curb the virus have erased sports calendars. ${ }^{123}$ Also, NGBs must pay most of their own operating costs. An example of challenges facing a smaller NGB involve USA Weightlifting, which, according to one report, has lost about 1,500 members in the two months since the onset of the COVID-19 crisis, resulting in around $\$ 100,000$ in reduced revenue. Additionally, several hundred competitions, ranging from elite national championships to local inter-club tournaments, have also been cancelled or postponed. Over 100 in-person coaching courses were cancelled. ${ }^{124}$

A few NGBs are more fortunate. USA Track \& Field ("USATF") is blessed with a lucrative funding source in Nike where a long-term agreement pays a

\footnotetext{
119 USOPC CEO Sarah Hirshland and chairwoman Susanne Lyons acknowledged the shortcomings of the organization at an annual meeting in the fall of 2019. See Minutes of USOPF Annual Meeting, Sept. 18, 2019.

120 See Rick Maese, U.S. Olympic Committee Changes Name to Recognize Paralympians, The Washington Post, June 20, 2019, https://www.washingtonpost.com/sports/2019/06/20/us-olympic-committee-changes-name-recognize-paralympians/ (accessed May 29, 2020).

121 See Rachel Bachman, U.S. Olympic Sports Groups Seek Government Aid, The Wall Street JournaL, April 12, 2020, https://www.wsj.com/articles/u-s-olympic-sports-groups-seek-govern-

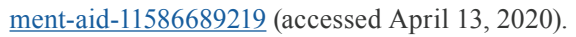

122 See U.S. Olympic Committee Changes Name To U.S. Olympic \& Paralympic Committee, June 30, 2019, https://www.teamusa.org/News/2019/June/20/US-Olympic-Committee-Changes-NameTo-US-Olympic-Paralympic-Committee

${ }^{123} I d$. ("The federal economic-rescue package [enacted in April 2020] allow[ed] certain employers to apply for loans to cover payroll, rent and utilities. Sports governing bodies believe they meet the criteria, including having fewer than 500 employees, and they're seeking or plan to seek aid alongside tens of thousands of other businesses and nonprofits.")

124 See Rob Williams, USA Weightlifting's Woes Paint Familiar Picture for Olympic NGBs, SPORTBusiness, https://www.sportbusiness.com/2020/05/usa-weightlifting-pivots-revenue-streams-online-to-mitigate-covid-19-financial-losses/ (accessed May 25, 2020).
} 
total of $\$ 400$ million and concludes in 2043. ${ }^{125}$ USATF also has sponsorship agreements with firms such as Hershey and Toyota. ${ }^{126}$

In 2018, the then-USOC entered into a joint venture with Los Angeles Olympic Organization Committee (known as LA 2028) to form U.S. Olympic and Paralympic Properties ("USOPP"). The purpose is to provide joint marketing efforts to the 2028 Games to be held in Los Angeles, CA. The agreement stipulates a baseline revenue to the USOC during the 2024 and 2028 quadrennials plus a share of revenues greater than a pre-determined revenue target. ${ }^{127}$ The USOC created the U.S. Olympic and Paralympic Foundation ("USOPF") in 2013 for the purpose of generating philanthropic support for the USOPC. ${ }^{128}$ Whether this effort is successful in the post-COVID-19 era remains to be seen.

\section{How the Law Shields the USATF and the NGBs}

The USOPC and NGBs have been granted certain judicial and statutory immunities that make challenges against their policies and practices difficult, if not impossible, to win. The immunities involve antitrust and constitutional claims. Some federal circuits have created an antitrust exemption over governing bodies, while 1998 amendments to the Sports Act denied state actor status for the USOPC and the NGBs, thereby insulating these bodies from constitutional challenges.

\section{A. The Antitrust Exemption}

It is almost a truism that professional sports leagues have long been vulnerable to antitrust concerns, in large part due to their cartel structure, which produces economic domination over the particular sport. ${ }^{129}$ However, due to the unique characteristics of professional sports leagues, the courts have often treaded gingerly into their alleged anti-competition activities, by either justifying what arguably would be anti-trust violations as "pro-competitive" under the "rule of

\footnotetext{
125 See Tripp Mickle, Nike Signs 23-Year Sponsorship Extension with USATF Valued at More than $\$ 400 M$, Sports Business Journal, April 17, 2014, https:/www.sportsbusinessdaily.com/Dai1y/Issues/2014/04/17/Marketing-and-Sponsorship/Nike-USATF.aspx (accessed May 15, 2020).

126 See USATF Sponsors, https://www.usatf.org/about/sponsors (accessed May 15, 2020).

${ }^{127}$ Id . at p. 15. LAOPP is an LLC owned $20 \%$ by the USOPC and $80 \%$ by LA 2028.

128 Id. at p. 20. The USOC made grants to the USOPF totaling, $\$ 12,599,000$ and $\$ 23,650,000$ for the year ended Dec. 31, 2018, and two-year period ended Dec. 31, 2018, respectively, which must be used by the USOPF exclusively for its own administrative and fundraising expenses.

129 See Thane Rosenbaum, The Antitrust Implications of Professional Sports Leagues Revisited: Emerging Trends in the Modern Era, 41 U. of MiAmI L. Rev. 730, 768 (1987) ("from other sports vulnerable to antitrust review").
} 
reason" standard of interpretation ${ }^{130}$ or by the creation of antitrust exemptions, either by statute ${ }^{131}$ or by the courts. ${ }^{132}$

It is also fair to say that the activities of Olympic governing bodies could also be subject to antitrust challenge, as they (1) exercise domination and control of a given market (the market for traditionally amateur sports) and (2) enact policies that could, at least theoretically, restrict competition to maintain that control. Examples would be sponsorship and broadcast agreements. The question has been raised as to whether these bodies have an anti-trust exemption created by the Sports Act. ${ }^{133}$ In at least three federal circuits, the answer is yes.

Rulings by the U.S. Courts of Appeals for the Ninth, Tenth, and Eleventh Circuits have concluded that such an immunity exists, while the Fifth Circuit denied the creation of an exemption. ${ }^{134}$ The rationale for the exemption is en-

${ }_{130}$ See Leah Farzin, On the Antitrust Exemption for Professional Sports in the United States and Europe, 22 JefFrey S. MoORAd SPORTS L.J. 75 (2015). ("Professional sports leagues have benefitted from the application of the Rule of Reason when their actions have been challenged as anticompetitive with courts refusing to apply the per se rule.")

131 See Sports Broadcasting Act of 1961, Pub. L. 87-331, §1, Sept. 30, 1961, 75 Stat. 732, 15 U.S.C. 1291 et seq.

132 See, e.g., Federal Baseball Club v. National League, 259 U.S. 200 (1922), (antitrust does not apply to baseball as it was not engaging in an activity in interstate commerce); Flood v. Kuhn, 407 U.S. 258 (1972) (upheld baseball's antitrust exemption based on past precedents, despite the conclusion that baseball's activities are clearly within interstate commerce); See also Powell v. NFL, 78 F. Supp. 777 (D. Minn. 1988), rev'd, 930 F.2d 1293 (8th Cir. 1989), cert denied, 111 S. Ct. 711 (1991). and McNeal v. NFL, McNeil v. National Football League, 764 F. Supp. 1351 (D. Minn. 1991) (series of cases interpreting the scope of the non-statutory exemption to the antitrust laws).

133 See David Hanselman and Joshua Eastby, A Potential Antitrust Pitfall For Amateur Sports Organizations, LAw360, March 28, 2019, https://www.law360.com/articles/1142671/a-potential-antitrust-pitfall-for-amateur-sports-organizations (accessed May 30, 2020) ("The situation for amateur sports organizations created under the Amateur Sports Act of 1978 is markedly different.[8] Where other sports organizations are typically subject to at least a partial antitrust review, when it comes to national governing bodies, the standard generally is 'all bets are off.'").

134 See JES Properties, Inc. v. USA Equestrian, Inc., 458 F.3d 1224, 1232 (11th Cir.2006) (United States Equestrian Foundation immune from antitrust liability where it set up scheduling rules to minimize competition conflicts). The case involved a challenge to a rule developed by the United States Equestrian Foundation that imposed a mileage distance for equestrian competitions. The purposes for the rule was: 1) "to concentrate elite riders into fewer competitions in order to yield the most competitive international equestrian team possible," and 2) "to promote equestrianism nationwide by forcing promoters to hold recognized competitions in more diverse locations." Id. at 1227. The Eleventh Circuit reasoned that, due to "the monolithic control" exercised by national governing bodies, "the question ... is whether the application of the antitrust laws to the facts of this case would unduly interfere with the operation of the ASA." It held that "[b]ecause the ASA requires [a national governing body] to promulgate rules to minimize conflicts in schedules, the imposition of antitrust liability for the promulgation of such a rule is plainly repugnant to the ASA; Behagen v. Amateur Basketball Ass'n of U.S., 884 F.2d 524, 529 (10th Cir.1989) (antitrust exemption inferred from ASA where basketball NGB established player eligibility rules). In this 
suring that the policies of the USOPC are "uniform" and preventing potentially extensive and costly litigation that would limit its powers to control the Olympic program. As one court stated: "Although [a national governing body] is a private actor, the monolithic control exerted by [a national governing body] over its amateur sport is a direct result of the congressional intent expressed in the Sports Act ..."135 This is exactly the kind of problem that comes about when a private actor takes on the role of a quasi-public entity. In an interesting mix of private and public responsibility, that kind of entity (in this case, the USOPC) is tasked with making broad restrictions to further its goal to streamline and control the Olympic movement in the US. On the other hand, it gives the organization a virtual carte blanche on decision making. The Fifth Circuit ruling involved a local, non-profit, volunteer soccer organization, with significant differences from the kind of national importance of an Olympic NGB. ${ }^{136}$

\section{B. Limitations on Constitutional Challenges to USOPC and NGBs Decisions}

The structure outlined by the original Amateur Sports Act (and retained in the 1998 amendments) granted only a limited role for Congress in overseeing the sport governing bodies. However, the question of whether Olympic sports organizations constituted state actors was first answered in the courts and then effectively enshrined in the 1998 Amendments to the Sports Act. ${ }^{137}$

case, In this case, the Tenth Circuit reversed a jury verdict in favor of a basketball player who challenged under the antitrust laws an eligibility rule developed by the national governing body for amateur basketball that prohibited a player from participating in amateur events if the player had participated in professional games. [citation omitted]. The Tenth Circuit held that the antitrust issue should not have gone to the jury because the eligibility rule was exempt from the antitrust laws under the ASA. [citation omitted]; and Gold Medal LLC v. USATF, 899 F.3d 712 (9th Cir. 2018) (antitrust exemption applied, rejecting a challenge to a ban on branded apparel during the Olympic Track and Field Trials). The Fifth Circuit denied the existence of such an exemption in Eleven Line, Inc. v. N. Tex. State Soccer Ass'n, Inc., 213 F.3d 198 (5th Cir. 2000) (the exclusionary activities of non-profit, volunteer-run soccer organizations should not be afforded implied antitrust immunity for a rule requiring soccer players, coaches, and referees to conduct soccer games only at "sanctioned" facilities,) The court held that the exclusionary activities of non-profit, volunteer-run soccer organizations should not be afforded implied antitrust immunity for a rule requiring soccer players, coaches, and referees to conduct soccer games only at "sanctioned" facilities, which did not include Eleven Line's for-profit soccer facility. The Gold Medal court distinguished this case from the others in large part because the national governing body for youth soccer did not issue the challenged rule or explicitly approve it. See Id. at 204.

135 See Gold Medal v. USATF, supra, 899 F.3d at 716.

136 See Eleven Line, Inc. v. N. Tex. State Soccer Ass'n., n. 135.

137 See 36 U.S.C. $\$ 220505$ (b)(9) bans private rights of action against the USOC or NGBs). 
The most notable ruling came from a federal district court that concluded the then-USOC was not a state actor. The case, DeFrantz v. United States Olympic Committee, ${ }^{138}$ involved a challenge by 25 athletes to the USOC's decision not to send an American team to participate in the 1980 Summer Games in Moscow. ${ }^{139}$ The decision to boycott the games was made after heavy pressure by President Jimmy Carter and Congress, ${ }^{140}$ as a response to the Soviet invasion of Afghanistan the year earlier.

In rejecting the plaintiffs' claim, the district court concluded that because the USOC was not a state actor it dismissed the due process violations claims, noting that "the USOC is an independent body, and nothing in its chartering statute gives the federal government the right to control that body or its officers."141 After the ruling in DeFrantz, but before the passage of the 1998 Amendments

138 See 492 F. Supp. 1180,02 (D.D.C. 1980)

${ }_{139} I d$. The USOC's vote denied the U.S. Olympic athletes the opportunity to compete in the wake of the invasion and occupation of Afghanistan by Soviet military forces.

$140 I d$. at 1184. ("the Administration strenuously urged a boycott of the Moscow games. On January 20, 1980, President Carter wrote the President of the United States Olympic Committee to urge that the USOC propose to the IOC that the 1980 summer games be transferred from Moscow, postponed, or cancelled if the Soviet forces were not withdrawn within a month. ... the United States House of Representatives passed, by a vote of 386 to 12, a Concurrent Resolution opposing participation by United States athletes in the Moscow Games unless Soviet troops were withdrawn from Afghanistan by February 20th. The Senate passed a similar resolution by a vote of 88 to 4 . .. the USOC's 86-member Executive Board held a meeting ... inviting White House counsel Lloyd Cutler to address them ... President Carter told members of the Athletes Advisory Council, an official body of the USOC, that American athletes will not participate in the Moscow summer games. ... the President sent a telegram to the president and officers of the USOC and to its House of Delegates, urging the USOC vote against sending an American team to Moscow. In a [subsequent speech, the President said that "if legal actions are necessary to enforce (my) decision not to send a team to Moscow, then I will take those legal actions." ... On April 10 and 11, 1980, the 13-member Administrative Committee of the USOC met in Colorado Springs and voted to support a resolution against sending a team to Moscow. Only Anita DeFrantz, a plaintiff in this action, dissented. ...") The USOC House of Delegates, on a secret ballot, passed by a vote of 1,604 to 798, a resolution adopting the boycott. $I d$. at 1184-85.

${ }_{141} I d$. at 1194. The decision also stated that if the USOC was a state actor, no violation could be found. The court also concluded that the USOC not only had the authority to decide not to send an American team to the Summer Olympics, but also that it could do so for reasons not directly related to sports considerations. Id. at 1189, and that the Amateur Sports Act does not confer an express or implied private right of right of action to maintain this suit, Id. at 1192. 
to the Act, other courts, including the U.S. Supreme Court, also upheld the DeFrantz court's conclusion that private rights of action are precluded by the law. ${ }^{142}$ DeFrantz dates from a time when the Olympic movement was far smaller, and amateurism was still the rule. However, as the Olympics became professionalized, some scholars have argued that the premise of DeFrantz is flawed, and that athletes do have protected property and liberty interests in their athletic eligibility. Law professor Dionne Koller noted that a sports body "can be held to constitutional standards in circumstances where the federal government has directed their actions" (as in the case of the USOC in the DeFrantz case). ${ }^{143}$ In addition, more recent applications of state actor doctrine show that courts have become more flexible in determining the relationship between the state and the ostensive private entity. ${ }^{144}$

With the passage of the 1998 amendments to the Sports Act, the question as to whether the USOPC and the NGBs are state actors became moot because, as noted earlier, those amendments specifically barred private causes of action against Olympic organizations, with few exceptions. ${ }^{145}$

142 See, e.g., Sternberg v. U.S.A. National Karate-Do Federation, 123 F.Supp.2d 659 (E.D.N.Y. 2000) (action claiming Title IX gender discrimination against an NGO for barring a women's team from competing in an international tournament could demonstrate state action); See also Lee v. U.S. Taekwondo Union, 331 F. Supp. 2 d 1252 (D. Hawai'i, 2004) (Former coach is able to sue for racial discrimination lawsuit under 42 U.S.C. 1981, See also Oldfield v. Athletic Congress, 779 F.2d 505, 507 (9th Cir.1985) (Ninth Circuit affirmed the summary judgment, holding that the Amateur Sports Act contained no express private right of action allowing an athlete to challenge his eligibility determination.). The Supreme Court concluded that the USOC was not a state actor, but that decision involved a trademark infringement case.

143 See Dionne Koller, How the United States Government Sacrifices Athletes' Constitutional Rights in the Pursuit of National Prestige, 2008 BYU L. REv. 1465 (2008) ("Such an approach would be targeted in that it would only apply to the individual circumstances of a particular case. [footnote omitted] Whether a court would apply the Constitution to the USOC or USADA in an athlete-eligibility dispute is an open question, although in some circumstances the USOC and USADA may engage in state action [footnote omitted].”)

144 See Brentwood Academy v. Tennessee Secondary School Athletic Association., 531 U.S. 288 (2001), where the court concluded that a privately funded state interscholastic athletic organization's "pervasive entwinement" with the state resulted in that organization's classification as a state actor. $I d$. at 313. This ruling expands the notion of "entanglement" that is distinguished from NCAA v. Tarkanian 488 U.S.179 (1988) (which concluded that the NCAA was not a state actor despite the fact that he was suspended from his coaching duties by a state university for alleged NCAA violations because the school did not act under color of state law under 42 USC $\$ 1983$, since the governing body (the NCAA) was not a state actor as it operated outside the state and was composed of both public and private member institutions.) Id. at 193.

145 See 36 U.S.C. $§ 220505$ (b)(9) (2001) 
In addition to the antitrust and constitutional issues, courts have also concluded that the Sports Act pre-empts actions based on state law, ${ }^{146}$ closing another avenue for claims against these organizations.

The limited or "static" view of state action with regard to organizations like the USOPC has been criticized as too formalistic and contrary to an earlier, more expansive view of the doctrine. ${ }^{147}$ However, as long as the 1998 amendment remains in the Sports Act (the 2020 Act did not change it), the question is moot. However, if this provision was excised in the future, a legitimate argument could be made that state actor status could be conferred. While it is true that government funding alone does not confer state actor status, ${ }^{148}$ if the USOPC will receive federal funding and is subject to the recommendations of the congressionally appointed commission, it is conceivable that a court may grant state actor status to hear constitutional claims by athletes and others regarding USOPC and NGB decision making.

\section{Empowering Olympic, Paralympic and Amateur Athletes Act of $\mathbf{2 0 2 0}$}

The sexual abuse scandals and the resulting criticisms of the Olympic governing bodies was the impetus for the first amendments to the Sports Act since 1998. Supported by present and former Olympic athletes, and other critics of the status quo, the new law, ${ }^{149}$ titled the Empowering Olympic, Paralympic and Amateur

\footnotetext{
146 See Pliuskaitis v. USA Swimming, 720 Fed.Appx. 481 (10th Cir. 2018) ("we agree with the district court that the Sports Act preempts Pliuskaitis's claims for breach of duty, breach of contract, breach of good faith and fair dealing, and tortious interference. We likewise agree with the district court that the defamation claim is untimely, and we affirm the district court's decision dismissing that claim.")

147 See Dionne Kohler, Frozen in Time: The State Action Doctrine's Application to Amateur Sports, 82 St. John's L. Rev. 183 (2008) ("T] his static conception of the USOC and NCAA as private actors has provided a powerful incentive for the government to pursue policy objectives, ... without its methods being subject to constitutional constraint.")

148 See Rendell-Baker v. Kohn, 458 U.S. 830 (1982) (court rejected state actor status for a private school receiving state funding); See also Jackson v. Metropolitan Edison, 419 U.S. 345, 350 (1974) ("The mere fact that a business is subject to state regulation does not by itself convert its action into that of the State for purposes of the Fourteenth Amendment.")

149 See Edward G. Williams and Nancy Hogshead-Makar, Co-Chairs The Committee to Restore Integrity to the USOC; Our Recommendations for an "Athletes First" Olympic Committee, Jan. 22, 2019, http://aroundtherings.com/site/A 75538/Title_THE-COMMITTEE-TO-RESTOREINTEGRITY-TO-THE-USOC-OUR-RECOMMENDATIONS-FOR-AN-ATHLETES-FIRSTOLYMPIC-COMMITTEE/292/Articles (accessed April 19, 2020). See also Olympians Rising: Recommendations to Congress: Reforming the U.S. Olympic Committee to Ensure Health and Livelihood of Athletes, Sept. 19, 2018, https://b4e28f76-alfb-478b-b91a-cd0786d4a572.filesusr. com/ugd/6c3074_b899564b76b14e989567335d0a9b4406.pdf (accessed May 18, 2020). This author was also a supporter of the new law.
} 
Athletes Act of 2020 (hereinafter referred to as the "2020 Sports Act"), ${ }^{150}$ passed unanimously in both houses of Congress, ${ }^{151}$ reflecting a bipartisan need to reform the Olympic movement-even in the midst of a polarized political environment.

The new Act amends various provisions of the original 1978 Sports Act and its 1998 amendments. Probably the most significant provision allows Congress to dissolve the USOPC's board of directors if it finds that the organization fails "to fulfill [its] duties purposes as described in the original Amateur Sports Act." 152 The duties include: "keep[ing] amateur athletes informed of policy matters and reasonably reflect the views of the athletes in its policy decisions; allow[ing] an amateur athlete to compete in any international competitions conducted by the particular body; and provid[ing] equitable support and encouragement for participation by women and ... individuals with disabilities; and encourage[ing]e and support[ing] research, development, and dissemination of information in the areas of sports medicine and sports safety." ${ }^{153}$ In addition, the 2020 Act permits Congress to "terminate the recognition of national governing bodies". ${ }^{54}$ This reform gives Congress a powerful role as a watchdog for these organizations and, coupled with more requirements for annual reports and audits, the USOPC and the NGBs will, for the first time, face a high level of scrutiny for their actions.

The second key portion of the bill may strengthen the hand of Congress in its oversight. It is the creation of a 16-member bipartisan commission called the "Commission on the State of U.S. Olympics and Paralympics" ("commission"). It has a mandate to investigate the Olympic governance system. ${ }^{155}$ Appointed by the chairman and ranking members of the Senate and House Commerce committees, ${ }^{156}$ the commission will have two co-chairs. ${ }^{157}$ Qualifications for membership require experience as an Olympic, Paralympic, or professional athlete; elite

\footnotetext{
150 See S. 2330, 116th Cong. (2020).

151 See Scott M. Reid, Senate Passes Powerful Olympic Reform Legislation, The Orange County Register, Aug. 4, 2020, https://www.ocregister.com/2020/08/04/senate-passes-powerful-olympic-reform-legislation/ (accessed Nov. 15, 2020) (Senate unanimously passed the bill); See also, Rick Maese, Olympics Reform Bill Passes House, Promising Sweeping Change after Abuse Scandals Rocked Sports, The Washington Post, Oct. 1, 2020, https://www.washingtonpost.com/ sports/2020/10/01/olympics-reform-bill-house-abuse/ (accessed Nov. 15, 2020) (House unanimously passed the bill).

152 See 36 U.S.C. $\$ 220551$

153 See 36 U.S.C. $\$ 220524$ (General Duties of National Governing Bodies)

154 See 36 U.S.C. $\$ 225522$

155 Id. at sec. 11

156 Id. Specifically, four members shall be appointed by the chairman of the Senate Committee on Commerce, Science, and Transportation of the Senate; four members by the ranking member of that Committee; four members shall be the chairman of the Committee on Energy and Commerce of the House of Representatives; and four members by the ranking member of the Committee.

${ }_{157} I d$. The co-chairs will be appointed by the respective Senate and House committees.
} 
coach; those involved in sports administration; and those with "public service relating to sports" or advocates for increased minority involvement in sports. ${ }^{158}$ Once created, the commission would have nine months to report to Congress, and can propose any policy changes in the method of governance. ${ }^{159}$

This commission has potentially earthshattering ramifications for the USOPC and the NGBs. The commission's mandate is to study the Olympic system and propose reforms. They include: the level of diversity in the Olympic system; an assessment as to whether the US is achieving the goals for the Olympic and Paralympic Games set by the United States Olympic and Paralympic Committee; the participation in amateur athletics of women, disabled individuals, and minorities; recruitment efforts; an evaluation of the functions of the NGBs; an analysis of the responsiveness of the NGBs to athletes; and an assessment of the finances and the financial organization of the United States Olympic and Paralympic Committee. ${ }^{160}$

Other notable provisions of the 2020 Act include a requirement that not less than one-third of the membership of the board of directors of the corporation shall be composed of amateur athletes; and not less than $20 \%$ of the membership of the board of directors of the corporation shall be composed of amateur athletes who are actively engaged in representing the US in international amateur athletic competition, or have represented the US in international amateur athletic competition during the preceding 10-year period. ${ }^{161}$ Additionally, the law requires the Olympic bodies to report child abuse to law enforcement, ${ }^{162}$ increases funding for the U.S. Center for SafeSport, and requires the creation of a public website that would contain a list of individuals who are barred from the USOPC or a national governing body. ${ }^{163}$ It also strengthens reporting and audit requirements of the USOPC to Congress and the president, including requiring such reporting to take place annually instead of every four years. Audit and reporting requirements include salaries and bonuses paid, along with how the organization prevents

\footnotetext{
158 Id.

159 See Caitlin Kim, Congress Passes Gardner and DeGette Backed Olympic Oversight Bill, CPR News, Oct. 1, 2020, https:/www.cpr.org/2020/10/01/congress-passes-degette-and-gardner-backedolympic-oversight-bill/ (accessed October 18, 2020).

16036 U.S.C. at sec. 11.

161 Id. at (b)(2).

162 Id. at 2230505 ("The duty of the corporation to amateur athletes includes the adoption, effective implementation, and enforcement of policies and procedures designed- (A) to immediately report to law enforcement and the Center any allegation of child abuse of an amateur athlete who is a minor; (B) to ensure that each national governing body has in place policies and procedures to report immediately any allegation of child abuse of an amateur athlete ...")

163 Id.
} 
sexual abuse of athletes. ${ }^{164}$ The new law establishes an athlete ombuds (the term "ombudsman" was retired) to provide independent advice to athletes about various governance issues, as well as reporting to the athletes' advisory council of a given organization with a focus on Safe Sport issues. ${ }^{165}$ It would be funded by the USOPC.

Unfortunately, the 2020 Act does not address the questions of governmental funding for Olympic bodies, in part because private funding has been part and parcel of the U.S. Olympic movement. Indeed, some have argued that government funding should not be the answer and permitting a more "capitalistic" approach to funding works better. ${ }^{166}$ However, the argument is weakened as a result of the COVID-19 pandemic for two principal reasons: (1) the future of sponsorship funding is unclear; and (2) cutbacks in NCAA programs in sports traditionally associated with the Olympics may force the NGBs to increase their budgets to make up this shortfall.

\section{A. Uncertain Sponsorship Support}

If the sponsorship funds dry out, both the USOPC and the particular NGB could suffer severe financial hardship. The fact that the USOPC and many of the NGBs applied for government funds early in the pandemic validates that concern.

In the month after the announcement of the postponement of the 2020 Tokyo Summer Olympics, not only did the USOPC cut its budget, but the NGBs in various sports also announced cutbacks in staffing and compensation, anticipating lower revenues caused by cancellation of events and, possibly, sponsorship losses. USATF laid off employees and its CEO took a 20\% salary cut (although

\footnotetext{
164 Id. at 220522 (the reports would include: description of the manner in which the organization- (i) carries out the mission to promote a safe environment in sports that is free from abuse of amateur athletes (including emotional, physical, and sexual abuse); and ... (B) a description of any cause of action or complaint filed against the organization that was pending or settled during the preceding calendar year; and (C) a detailed statement of - (i) the income and expenses of the organization; and (ii) the amounts expended on stipends, bonuses, and services for amateur athletes, organized by the level and gender of the amateur athletes ... )

${ }_{165}$ Id. at 220509(b)

166 See Emily Dunham, No Federal Funding for U.S. Olympians, The Daily Signal, Feb. 7, 2014, https://www.dailysignal.com/2014/02/07/federal-funding-us-olympians/ ("What seems like unnecessary commercialism is actually capitalism at work. International Olympic partners and the national team sponsors make the Games possible and - at least in the United States - without costing the taxpayers a dime.")
} 
his salary remains quite generous). ${ }^{167}$ Anticipating a significant loss of revenue, USA Cycling announced layoffs and furloughs, and USA Rugby filed for bankruptcy. ${ }^{168}$

One can argue that sponsors could be catalysts for change by using their financial wherewithal to mandate reforms in the way the USOPC or the NGBs operate. That is possible, but not likely. Consider USA Gymnastics. Its sponsors have fled the organization and its future is cloudy in the wake of lawsuits by sexual abuse victims and a bankruptcy filing. ${ }^{169}$

The current structure makes it difficult for all but the best athletes to have financially secure sponsorship agreements, In an implicit admission of this problem, the USOPC, in an attempt to ameliorate this situation, will permit more athletes to monetize themselves, albeit in a limited way. Set to launch in 2021, this group marketing program will initially be available to only top finishers - top eight for individuals or top six for team events - at the most recent world championship or equivalent event, as determined by each sport's national governing body. Athlete members who opt into this group marketing scheme will receive only $\$ 1,250$ per year to make their name, image, and likeness available for USOPC partners to use in marketing and activations. ${ }^{170}$

167 See Michael Pavitt, USA Track \& Field Chief to Take Pay Cut as Organisation Lays Off Seven Staff, Inside THE GAMES, April 18, 2020, https://www.insidethegames.biz/articles/1093288/usatrack-and-field-pay-cut-lay-offs\#.XpzB2IyZmDk.twitter (accessed April 19, 2020). ("Numerous competitions have been either postponed or cancelled due to the pandemic. This included the US Olympic Trials in Eugene, Oregon, which will move to 2021 following the postponement of the Tokyo 2020 Olympic Games to next year. ... [t]he USATF Under-20 Championships and the National Youth Outdoor Championships.). The decrease in USATF CEO Max Siegel's salary of over $\$ 1$ million (reported in the 2017 tax returns would still result in a very healthy level of compensation).

${ }_{168}$ Id. USA Cycling cut $15 \%$ of the organisation's staff, with a further $25 \%$ placed on furlough because it was expecting a $30 \%$ loss of revenue due to the coronavirus pandemic and its impact on events. A major reason that USA Rugby filed for bankruptcy was the financial constraints caused by the pandemic.

169 See Des Bieler, Amid Sexual Assault Scandal, USA Gymnastics Loses Major Sponsors, WASH. Post, Dec. 14, 2017, https://www.washingtonpost.com/news/early-lead/wp/2017/12/14/amid-sexual-assault-scandal-usa-gymnastics-loses-major-corporate-sponsors/ (accessed May 16, 2020) ("Rocked by the sexual assault scandal involving former team physician Larry Nassar, USA Gymnastics has lost a pair of major corporate sponsors, Procter \& Gamble (P\&G) and Kellogg's."). See also Suzanne Krowiak, Ask Me Anything: Li Leung, USA Gymnastics CEO, Indianapolis MonThLY, Sept. 9, 2019, https://www.indianapolismonthly.com/arts-and-culture/circle-city/askme-anything-li-li-leung-usa-gymnastics-ceo (accessed May 16, 2020).

170 See Chris Smith, USOPC Launching New Marketing Portal For Team USA Athletes, sportsbusinessdaily.com, Nov. 17, 2020, https://www.sportsbusinessdaily.com/Daily/Issues/2020/11/17/ Marketing-and-Sponsorship/USOPC-Marketing.aspx?ana=mk sbd da emda (accessed Nov. 17, 2020) 


\section{B. The NCAA May No Longer Be a Lifeline for Olympic Athletes}

One of the peculiarities in the U.S. Olympic system is that college athletes are under the control of a different organization, which sets its own rules and provides its own funding through its member schools. The National Collegiate Athletic Association ("NCAA") has governed collegiate sports for over a century and establishes standards for eligibility based on the notion of amateurism that the Olympic movement has long eschewed. ${ }^{171}$ Many, but not all, of the Olympic sports are part of the NCAA regimen, and many Olympians came from the NCAA ranks, especially in track and field and swimming. ${ }^{172}$ In addition to track and swimming, other sports in the NCAA and Olympic orbits include diving, weightlifting, fencing, gymnastics, women's field hockey, rowing, volleyball, rifle/shooting, wrestling, golf, tennis, water polo, skiing, and baseball/softball (2021 only). ${ }^{173}$ While NCAA participation in track is robust all over the country, there are relatively few schools that offer programs in sports such as rifle, skiing, water polo, and gymnastics. ${ }^{174}$ Other sports, such as figure skating, curling, and biathlon, are not NCAA sports.

Student-athletes in the NCAA sports system have had certain financial advantages over their non-collegiate counterparts. Many receive full or partial scholarships, which cover tuition, room and board, and meals. ${ }^{175}$ Therefore, these student-athletes do not have to bear the costs associated with training and competing in their sport. As an example, those who participate in figure skating could

\footnotetext{
171 See NCAA Constitution 2019-2020, sec. 2.9 ("The Principle of Amateurism") and Division I Manual 2019-20, 12.01 (General Principles of Amateurism), https://web3.ncaa.org/lsdbi/reports/ getReport $/ 90008$

172 See Ross Dellenger and Pat Forde, A Collegiate Model in Crisis: The Crippling Impact of Schools Cutting Sports, SPORTS IlluSTRATED, June 11, 2020, https://www. si.com/college $/ 2020 / 06 / 11 /$ college-sports-program-cuts-ncaa-olympics?suid=5c$\underline{\mathrm{clc} 2 \mathrm{c} 924 \mathrm{c} 17 \mathrm{c} 4939479167 \& u t m}$ source $=$ Sailthru\&utm medium $=$ email\&utm campaign $=\mathrm{SI} \% 20$ Extra\%20061120\&utm term=SI\%20Extra\%20-\%20USE\%20THIS\%20-\%20List (accessed July 8, 2020) ("Sarah Wilhelmi, the U.S. Olympic and Paralympic Committee's director of college partnerships says $88 \%$ of American summer Olympians in Rio had played their sport in college, and in the 2018 Winter Games, one-third of Americans were former college athletes.")

173 See Steve Dittmore, The Ramifications of Olympic Sports Elimination Due to Covid-19, Athleticdirectoru.com, April 9, 2020, https://www.athleticdirectoru.com/articles/more-universitiesmay-nee-to-eliminate-sports-and-that-would-be-bad-for-the-usopc-but-should-it-matter/ (accessed May 16, 2020).

174 See NCAA 2018-19 Participation Study, Men's Sports; NCAA 2018-19 Participation Study, Women's Sports, pp. 82-83, https://ncaaorg.s3.amazonaws.com/research/sportpart/2018-19RES SportsSponsorshipParticipationRatesReport.pdf (accessed April 7, 2020);

175 See NCAA Division I Manual, 15.02 (Institutional Financial Aid)
} 
incur hundreds of thousands of dollars in expenses before those very few elite skaters attain Olympic-level status. ${ }^{176}$

Consequently, there has been a strong connection between collegiate sports and the Olympic movement. At the 2016 Summer Games, more than $80 \%$ of the U.S. national team (more than 1,000 Olympians overall) currently or formerly competed in college beforehand. ${ }^{177}$ For the 2018 Winter Games in PyeongChang, South Korea, that number was $148 .{ }^{178}$ The NCAA even allows some prize money to be collected without affecting eligibility. ${ }^{179}$

Athletic expenses are a significant part of an institution's budget. ${ }^{180}$ The postCOVID-19 environment has the potential to cause disruption in the traditional collegiate system. In the spring of 2020, a survey of athletic directors from Division I schools painted a bleak financial picture of college sports based on the impact of COVID-19 on the financing of their operations. Eighty-six percent of the Football Bowl Subdivision ("FBS") athletic directors believed their universities will require their athletic departments to make "financial sacrifices" because of the crisis, which will involve significant decreases in revenues. ${ }^{181}$ Remedies include eliminating certain sports and laying off staff if finances become too tight. ${ }^{182}$ In

\footnotetext{
176 See Kaitlin Mulhare, This Is the Insane Amount of Money it Takes to Become an Olympic Figure Skater, Money Magazine, Feb. 9, 2018, https://money.com/olympic-figure-skating-costs/ (accessed May 16, 2020) ("Coaching fees, travel expenses, and physical therapy and athletic conditioning to keep the body operating at elite levels add up. But figure skating is among the priciest, with costs running more than $\$ 35,000$ a year and as much as $\$ 50,000$ annually by some estimates.")

177 See Olympians Made Here, NCAA.org, http://www.ncaa.org/about/resources/media-center/ olympians-made-here (accessed April 7, 2020). Most were former collegiate athletes at the time of their Olympic experience. See Putting Rio into Reach, NCAA.org, http://www.ncaa.org/about/ resources/media-center/feature/putting-rio-within-reach (accessed April 7, 2020).

178 See Olympians Made Here, n.164.

179 Id.

180 See NCAA Division III 2018-19 Facts and Figures, ncaaorg.s3, https://ncaaorg.s3.amazonaws. com/about/d3/2018-19D3 FactandFigures.pdf (accessed May 16, 2020). (average operating expenses range from about $\$ 2.4$ million for schools without football to almost $\$ 4$ million for school with a football program).

${ }_{181}$ See Dennis Dodd, College Sports' Bleak Financial Future in Wake of Coronavirus Pandemic Apparent in AD Survey, CBSSports.com, April 2, 2020, https://www.cbssports.com/college-football/news/college-sports-bleak-financial-future-in-wake-of-coronavirus-pandemic-apparent-inad-survey/amp/? twitter impression=true\&fbclid ("Over one-third of ADs forecast at least a 30 percent decrease in revenue for the 2020-21 academic year.") =IwAR04gclSxbeK_5_8wih2ufmgpyJWpP2zdUn3V92KUv5emQ0cjeu4CJcPMgM (accessed April 7, 2020).

182 Id.
} 
addition, a reported letter from five athletic conference commissioners pointed out that the situation was the "direst financial crisis since at least the Great Depression." 183 As of summer 2020, many colleges have already announced cuts in their athletic budgets and some of the cuts included the elimination of some sports that are Olympic sports. ${ }^{184}$

This could mean that some Olympic sports could be imperiled. If fewer schools offer competitive varsity programs, the option to pursue college as a way to subsidize one's training may evaporate for some athletes, forcing them to incur greater expenses or drop out of participation. It may also increase competition for grant money through the NGBs that offer it, or through the grant-based NEAtype systems advocated in this article. At this time, it is too early to say.

Even without COVID-19, the Olympic and Amateur Sports governing bodies need a secure funding mechanism. COVID-19 makes the case more compelling. And the bipartisan Commission on the State of U.S. Olympics and Paralympics set up as part of the 2020 Act should make recommendations on governmental funding, as well as improved transparency and governance issues.

\section{The Reforms the Commission Should Consider in its Report to Congress}

\section{A. Public Funding of USOPC and NGBs}

As noted, even before the COVID-19 pandemic, funding of the USOPC and the NGBs was haphazard and inconsistent. Although the 2020 Sports Act did not address government funding, the commission should and consider the following proposals. A few may be familiar, but others are more novel. A government

\footnotetext{
183 See Rich Perelman, Financial Implosion of College Athletics Now Threatens Olympic-Sport Programs in the U.S., The Sports Examiner, April 15, 2020, http://www.thesportsexaminer. com/lane-one-financial-implosion-of-college-athletics-now-threatens-olympic-sport-programs-in-the-u-s/?fbclid=IwAR1i8GPM2Kn7kgVFWXVUF_OB0xZ1HHUIr6J93T4g_OJJYN-

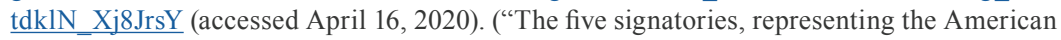
Athletic Conference, Conference USA, Mid-American Conference, Mountain West Conference and the Sun Belt Conference, ... sought "temporary relief from several regulatory requirements for a period of up to four years, "including dropping the minimum to 16 varsity intercollegiate sports for Division I status and offering a minimum of 200 athletics scholarships (or spent $\$ 4$ million) annually;" to provide "short-term relief ... [to] facilitate the opportunity for institutions to retrench and rebuild the financial structures of the institution."

184 See Bill Koch, Brown University Will Cut 11 of its Varsity Sports, The Providence Journal, May 28, 2020, https://www.providencejournal.com/sports/20200528/brown-university-will-cut11-of-its-varsity-sports (accessed May 30, 2020) (The affected sports include men's and women's fencing, men's and women's golf, women's skiing, men's and women's squash, women's equestrian, men's indoor track and field, men's outdoor track and field, and men's cross country, which will all transition to club status.)
} 
funding regimen, coupled with greater accountability and transparency, would be beneficial for all stakeholders in the U.S. Olympic movement.

Several ideas will be outlined, such as direct appropriations from the federal budget, direct grants to targeted local and regional bodies within the governing bodies, and/or a tax check-off system whereby taxpayers can contribute directly.

\section{Direct Appropriations by Congress}

Based on the recommendations of the commission and either an amendment to the law or by budget appropriation, Congress could help fund the USOPC and NGBs through direct appropriations by either an annual appropriation or a multiyear funding mechanism that coincides with the scheduling of the Olympics. Another option is a staggered four-year funding period to dovetail the different cycles for Summer and Winter Olympic sports. The method of distribution may vary. Congress could propose a lump-sum fund for the USOPC, which would disperse amounts to the various NGBs based on a formula that includes number of members, number of events, and number of participants in particular events, or a specific amount for each of the bodies. The commission would decide which it thinks is best.

Before the pandemic, it was estimated that the USOPC's budget would be over $\$ 1$ billion over four years. If Congress would appropriate that amount (either annually of quadrennially), and the USOPC raises even a portion of the estimated $\$ 400$ million predicted, it would have more funding than before. ${ }^{185}$ And it would be consistent.

\section{Income Tax Check-Off Option}

Another way to raise funds would be to utilize a method that is used for funding presidential elections and certain prescribed charitable organizations: an optional check-off on federal and state tax returns. ${ }^{186}$ In the 1980 s, nine states replicated this program, which at the time was the only direct public funding program for Olympic sports. However, it was not successful, generating only \$3 million between 1986 and $1991 .{ }^{187}$ Presently, on many state tax returns, a similar system

\footnotetext{
185 See Bachman, n. 99.

186 First appearing on the federal income tax form in 1972, the best known is the Presidential Election Campaign fund. By checking a box on the Federal return, taxpayers could direct $\$ 3.00$ of their tax liability to the fund. It does not increase their payment or decrease their refund, but rather redirected a portion of the government's spending revenue to public campaign funds. See Kathleen Quinn, Income Tax Checkoff Programs, National Conference of State Legislatures, May 2016, https://www.ncsl.org/research/fiscal-policy/income-tax-checkoff-programs.aspx (accessed February 23, 2020).

187 See Michael Janofsky, Olympics: U.S.O.C. Seeks Fund Using State Lotteries, N.Y. Times, Oct. 3, 1991, https://www.nytimes.com/1991/10/03/sports/olympics-usoc-seeks-funds-using-state-lotteries.html (accessed July 9, 2020).
} 
for charitable funding exists for sports-related projects, although the types of charities and the permanence of these check-offs vary greatly. ${ }^{188}$

The commission could consider a provision recreating this kind of check-off system. At least, it could be one method of raising funds for the USOPC and the national governing bodies. In conjunction with state tax schemes, states could utilize their own check-off systems to tailor funding for NGBs that are located within their states, or more specifically, local affiliates of such organizations or even local non-profit gyms and training centers for potential Olympic athletes.

The chief concern of this proposal centers on the inconsistencies in the amount of money raised each year, which could make accurate budgeting difficult. However, it may serve as a "stop-gap" idea, given that the economic effects of COVID-19 limit the possibility of funding in the near future. The check-off may or may not continue indefinitely and even if more secure methods of funding would be available in the future, it could remain as a way to receive extra money each year.

And the amounts could be significant. In 2020, over 165 million taxpayers filed returns. ${ }^{189}$ Even if only $20 \%$ of those taxpayers checked off a $\$ 3.00$ contribution, almost $\$ 100$ million would be raised every year. To put this in perspective, it would more than double the amount that the USOPC paid to the various summer Olympic governing bodies in $2016 .{ }^{190}$ If $50 \%$ of taxpayers utilized this option, the amount would be about $\$ 250$ million, not far from the total sponsorship and licensing revenues received by the USOPC in 2018, an Olympic year. In non-Olympic years, the taxpayer amount would be far greater than the sponsorship fees. ${ }^{191}$

\footnotetext{
${ }^{188}$ Id. ("Colorado has capped the number of checkoffs at 15 , and employs a minimum contribution requirement and a queue for new programs seeking to make it onto the form. Oregon, the state offering the most checkoffs, has an application process and a "Charitable Checkoff Commission," a five-member committee that determines which checkoffs can be included on each year's state tax return.") ("Between 2000 and 2014, Wisconsin's income tax form included a Green Bay Packer's Football Stadium checkoff box to help raise funds for a $\$ 295$ million renovation project. California has included a Sea Otter Fund checkoff since 2007. The Olympic training center in Lake Placid, N.Y., home to the 1980 Winter Olympics, still holds a place on New York's checkoff list. In addition, while not a checkoff contribution, Maine residents can purchase state park passes in the checkoff portion of its tax return.")

189 See Filing Season Statistics for Week Ending October 16, 2020, IRS.gov, https://www.irs.gov/ newsroom/filing-season-statistics-for-week-ending-october-16-2020 (accessed Nov. 15, 2020).

190 See Ben Fischer, Medal-Rich Teams Draw Even More Funding from USOC in 2016, SPORTS Business JournaL, May 22, 2017, https://www.sportsbusinessdaily.com/Journal/Issues/2017/05/22/ Olympics/USOC.aspx (accessed May 18, 2020).

191 See United States Olympic Committee, 2018 Annual Report, p. 16, https://www.teamusa.org/ footer/finance (accessed April 11, 2020).
} 


\section{Localized Funding: An NEA Grant-Like System}

Since its creation in 1965, the National Endowment for the Arts ("NEA") has created a panel-review mechanism for funding local arts organizations. ${ }^{192}$ The NEA provides grants for organizations engaged in "exemplary projects" involving different facets of the arts (performing and visual) in all 50 states, the District of Columbia, and U.S. territories. ${ }^{193}$

Projects can be based on one specific event or a group of activities. ${ }^{194}$ Funding is available through four categories: (1) organizations exhibiting "artistically excellent projects that celebrate our creativity and cultural heritage;" (2) those that service underserved populations; (3) projects that integrate arts, culture, and design activities into efforts that strengthen communities by advancing local economic, physical, and/or social outcomes; and (4) organizations engaged in particular research projects. These grants, whose monies range from $\$ 10,000$ to $\$ 200,000$ (depending on the category) are matching grants, meaning that the organization must also raise an equivalent amount from other sources. ${ }^{195}$

Applications are reviewed by panelists who comprise a diverse group of arts experts and other individuals, including at least one knowledgeable layperson, with broad knowledge in the areas under review. These are done in "closed session." These recommendations are forwarded to the National Council on the Arts, where they are reviewed in open session. Then, a funding decision is made. ${ }^{196}$ The one pre-requisite is that the organization must be a not-for-profit, tax exempt 501c(3) entity. ${ }^{197}$

A similar system could be employed to localized athletic organizations as part of a new Sports Act. Taking the example of USA Track \& Field, which has many local affiliates, say that a local running club wishes to sponsor events geared to helping children exercise and thereby preventing childhood obesity. The organization could apply for a grant of $\$ 25,000$ to recruit interested students

\footnotetext{
192 See Grant Review Process, National Endowment for the Arts, https://www.arts.gov/grants/ apply-grant/grants-organizations/grant-review-process (accessed May 16, 2020).

193 See Grants for Organizations, National Endowment for the Arts, https://www.arts.gov/grants/ apply-grant/grants-organizations (accessed March 1, 2020). ("Grants for organizations support exemplary projects in artist communities, arts education, dance, design, folk and traditional arts, literary arts, local arts agencies, media arts, museums, music, musical theater, opera, presenting and multidisciplinary works, theater, and visuals arts.")

194 Id.

195 Id. They are officially titled "Grants for Arts Projects," "Challenge America," "Our Town," and "research Projects."

196 See Grants for Arts Projects: Application Review, National Endowment for the Arts, https:// www.arts.gov/grants-organizations/gap/application-review (accessed March 1, 2020).

197 See Grants for Arts Project: Applicant Eligibility, https://www.arts.gov/grants-organizations/ gap/applicant-eligibility (accessed March 1, 2020).
} 
in gym classes, bus them to events, buy uniforms, and get them to engage in sprints or middle distances at their local track. It could also be used to repair the facility or buy new equipment in furtherance of that goal. The promise of governmental funding can spur private donation efforts. Like the NEA, an independent group of reviewers can be tasked to evaluate the application and debate its merits. The reviewers could be appointed from a list, much like independent arbitrators are from organizations such as the American Arbitration Association.

\section{Direct Athlete Funding}

It is true that many NGBs have programs to fund elite athletes, but despite that, many, if not most, Olympic athletes do not receive much compensation for their athletic prowess. While superstars like Michael Phelps, the most successful swimmer in Olympic history, has earned $\$ 55$ million in $2014,{ }^{198}$ he is the very rare exception. Many, if not most, do not make enough from their sport to sustain a living. Fifty percent of the top 10 track athletes in their event earned less than $\$ 15,000$ a year from their sport. ${ }^{199}$ The high cost of training is largely borne by the athletes and their family, and some have had to file for bankruptcy because of the resulting debts. ${ }^{200}$

\section{State Funding}

While this article focuses on federal funding, there could be opportunities where states can also fund more localized clubs, groups, or individual athletes through a tax deduction system. Individual states can enact their own laws to create funding systems and, given that states control localities more than the federal government does, it can be argued that states can be more effective in targeting strong candidates for funding. Revenues could be derived from direct funding or a tax check-off system that was explained earlier.

\section{A National Lottery}

The idea of a lottery for Olympic funding is not new. It has been used to fund national Olympic committees in the United Kingdom and other countries like

\footnotetext{
198 See Edward Etzel, Opinion: When the Olympic Games Don't Pay the Bills for Team USA Athletes, Marketwatch.com, Feb. 12, 2018, https://www.marketwatch.com/story/when-the-olympic-games-dont-pay-the-bills-for-team-usa-athletes-2018-02-11

199 Id.

200 In 2012, the mother of gymnast Gabby Douglas filed for bankruptcy in part due to the costs of her training and living away from home. See Kimberly Palmer, Why Olympic Athletes' Families Go Broke, U.S. News \& World Report, August 7, 2012, https://money.usnews.com/money/blogs/ alpha-consumer/2012/08/07/why-olympic-athletes-parents-go-broke?mod=article inline (accessed March 31, 2020).
} 
Brazil, Denmark, and Switzerland. ${ }^{201}$ The UK's system has been particularly successful. In 2016, three-quarters of the UK's Olympic funding came from lottery proceeds that totaled $\$ 460$ million $^{202}$ and is credited in helping that nation achieve second place in gold medals awarded at the 2016 Summer Games. ${ }^{203}$ The lottery provides generous funding to elite athletes, with amounts as high as about $\$ 100,000$ a year. ${ }^{204}$ Despite the success, critics have noted that grassroots level sports do not share in the spoils of this system. ${ }^{205}$

In the early 1990s, a "test program" was created in the US to fund athletes for the 1992 Winter and Summer Games with the hope of creating a larger fund for the 1996 Atlanta Summer Olympics. ${ }^{206}$ The program had only limited success and was not extended. While a national Olympic lottery in the US could be an alternative to a government funding approach, with multiple state and multi-state lotteries in existence, it is not assured how much would be raised by yet another lottery.

Another method of indirect public funding was the creation of a series of "Olympic coins" to raise money for the 1984 Summer Olympics in Los Angeles. Congress passed legislation authorizing the U.S. mint to do just that. ${ }^{207}$ It was

\footnotetext{
201 See Brazilian Olympic Sport Suffers from Lottery Funds in Free Fall, GAmEs Magazine BrazIL, April 27, 2020. https://www.gamesbras.com/english-version/2020/4/27/brazilian-olympic-sport-suffers-from-lottery-funds-in-free-fall-17198.html, (accessed July 2, 2020) (outlining the losses in funding due to COVID-19 pandemic as initial estimates of $\$ 58$ million was not be achieved); Sport Receives Financial Support from State Football Pools and the National Lottery, Ministry of Culture Denmark, https://english.kum.dk/policy-areas/sport/financial-support/, (accessed July 2, 2020); Swiss Olympic to Put SFr42m Lottery Funding Back into National Sport, SPORTCAL, Nov. 25, 2019, https://www.sportcal.com/News/Search/128892 (accessed July 2, 2020). 202 See Tim Wigmore, Britain's Huge Investment in Summer Olympic Sports Pays Off, N.Y. Times, Aug. 22, 2016, https://www.nytimes.com/2016/08/23/sports/olympics/britains-huge-investment-insummer-olympic-sports-pays-off.html (accessed June 21, 2020).

203 Id.

204 Id. ("In 2016, athletes who have earned a podium level finish at the Games receive up to about $\$ 37,000$ a year from U.K. Sport, which allocates funding for the Games, to contribute to their living and personal sporting costs. U.K. Sport also gives leading athletes support worth about $\$ 47,000$ to about $\$ 79,000$, which is spent on coaching and training. Each medal that Britain won in Rio has cost, on average, more than $\$ 6.5$ million.”)

${ }_{205}$ Id. ("U.K. Sport's ruthless approach to funding has also been criticized for prioritizing sports favored by more affluent people, like rowing and equestrian, over those that are more popular with poorer socioeconomic groups but offer scant medal hopes, like basketball and volleyball.")

206 See Michael Janofsky, Olympics: U.S.O.C. Seeks Fund Using State Lotteries, N.Y. Times, Oct. 3, 1991, https://www.nytimes.com/1991/10/03/sports/olympics-usoc-seeks-funds-using-state-lotteries.html (accessed July 9, 2020).

207 See Olympic Commemorative Coin Act, P.L. 97-220, 96 Stat. 222 (1982). The law authorized release of a commemorative 1983 and 1984 silver dollars and a $\$ 10$ gold Olympic coin in uncirculated and proof sets.
} 
estimated that those sales raised $\$ 40$ million for the USOC. ${ }^{208}$ Given the costs of producing the coins and the decline in interest in numismatics, it would be difficult and impractical to replicate such a program today.

\section{B. More Accountability and Transparency from the USOPC and the NGBs}

In return for Congressional funding - whether it be funds directed to the USOPC, NGBs, individual athletes, or local athletic facilities-those receiving the funds will be subject to far more scrutiny than has been the case in the past. The Commission on the State of U.S. Olympics and Paralympics, in making its recommendations, should consider employing best corporate practices, whether in its reporting of relevant information or disclosure of relevant documents. These disclosures must ensure public accountability will involve more than simply releasing IRS tax forms. The commission should consider the following ideas.

\section{Release of Information Outlining Salaries, Bonuses, Expenses to Congress, and the Commission on the State of U.S. Olympics and Paralympics}

As non-profit corporations, the USOPC and NGBs release annual reports, which include audited financial statements and tax information. These documents are found on the organizations' respective websites and are filed with the Internal Revenue Services ("IRS"). ${ }^{209}$ All too often, they put the best light on the organization, something typical of annual reports in the business and non-profit world generally. ${ }^{210}$ The annual reports also include general statements about the organization's programs for athletes, training facilities, media and promotions, and a financial statement. ${ }^{211}$

The 2018 IRS Form 990 outlines the salaries and bonuses paid to the staff of the USOC. Suffice it to say, many were very well compensated. CEO Sarah

\footnotetext{
208 See Wood, n. 23 https://www.nytimes.com/1983/07/03/magazine/olympics-84.html (accessed July 9, 2020).

209 See Team USA - Finance, https://www.teamusa.org/footer/finance (accessed April 11, 2020). As of that date, annual reports from 2014-18 and listed as are tax disclosures and audited statements.

210 For example, the 2018 annual report states that the USOPC "Create[d] a stable, safe and supportive training environment for elite U.S gymnasts, while evaluating USA Gymnastics' reforms and status as the recognized NGB in the United States" and "[t]he [USOPC] was a central driver of organizational reform at USA Gymnastics, forcing the resignation of both USAG's CEO and full board of directors." The report also noted how the [USOPC] "Supported elite U.S. Gymnasts and [engaged in the] continued evaluation of USA Gymnastics.” See United States Olympic Committee, 2018 Annual Report, p. 16, https://www.teamusa.org/footer/finance (accessed April 11, 2020).

211 See 2018 Annual Report, p. 34.
} 
Hirshland received just over $\$ 200,000$ in salary and a bonus of $\$ 80,000 .^{212}$ But to her credit, that is less than the annual compensation for the prior interim CEO, Susanne Lyons, who received a $\$ 304,000$ base and a $\$ 100,000$ bonus. ${ }^{213}$ Every listed staff member received total compensation between the $\$ 300,000-\$ 500,000$ range, except for the chief marketing officer, who made over $\$ 850,000$ and the former CEO, who had a buyout that brought his paycheck to almost $\$ 3$ million. ${ }^{214}$

The USOPC is not the only organization that has paid some of its leading employees well. Regarding the NGBs, similar questions about compensation and expenses occur. USA Track \& Field's CEO, Max Siegal, earned more than \$4 million in salary and "other compensation" in $2018 .{ }^{215}$ Even taking aside the more than $\$ 3$ million in retirement income (to be paid over a period of several years), his base pay was $\$ 611,014$, and he earned a bonus of $\$ 500,000$ as well as $\$ 146,160$ in "other reportable compensation," for a total of $\$ 1,257,174 .{ }^{216}$ The CEOs of USA Swimming, USA Triathlon, and the Executive Director of USA Figure Skating were also well-compensated in 2018. However, smaller NGBs pay far less. For example, USA Archery's CEO earned just over \$160,000. ${ }^{217}$

The compensation issues raise questions, which could be addressed by the appointment of an inspector general with auditing powers under a new Sports Act. In addition, as will be discussed, the new Commission for Olympic and Paralympic Sports could issue standards for compensation.

\footnotetext{
${ }^{212}$ See United States Olympic Committee, 2018 IRS Form 990, Schedule J, Part 2, https://www. teamusa.org/footer/finance (accessed April 12, 2020).

213 Id.

${ }^{214} I d$. The list is as follows: Morane B. Kerek, Chief Financial Officer, \$364,949; Richard W. Adams, Chief of Paralympics, \$433,276; Alan R. Ashley, Chief Sport Performance, \$591,823; Lisa P. Baird, Chief Marketing Officer, \$864,847; Jon M. Denney, Chief Development Officer, $\$ 573,331$; Kevin E. Penn, Chief of Business Operations, \$440,824; Russell C. Huebner, Former Chief of Paralympics, \$336,267; Brian H. Gordon, SVP, Marketing and Media, \$383,169; Michael J. O'Conor, SVP, Business Development, \$402,220; Mitchell Pol, SVP Partnership Marketing, $\$ 499,573$; Patrick D. Sandusky, Chief Communications, $\$ 463,800$; Peter C. Zeytoonjian, SVP Marketing, \$458,661. Scott Blackmun, the departing CEO, received a buyout of almost $\$ 2.5$ million in addition to his base and bonus, resulting in a total of $\$ 2,999,737$. Given the recent layoffs and furloughs and the reductions in the USOPC's budget, there may be salary reductions for those executives who remain with the organization.

215 Id. USA Track \& Field, 2018 IRS Form 990, Part VII, https://usatf.org/about/financials/tax-information. See also, Sarah Lorge Butler, After Delay, USATF Releases 2018 Tax Information and Reports Big Salary for CEO, RunNER's WorLD, April 22, 2020, https://www.runnersworld.com/ news/a32243052/usatf-releases-2018-tax-information/?fbclid=IwAR1DGmjcbHqw3OTVcKMVydPsc0gVHhdHaAAoOVqepLXuQzgWpQlMeujofBU (accessed April 22, 2020).

216 Id. Timothy Hinchey, the CEO of USA Swimming, made \$721,101 during 2018. Brett Harris, the CEO of USA Triathlon, made $\$ 413,480$. David Raith, the executive director of USA Figure Skating, made $\$ 363,036$.

217 See USA Archery, 2018 IRS Form 990, Part VII, section A.
} 


\section{Disclosure of Sponsorship Agreements}

The USOPC and many NGBs have sponsorship agreements, some of them in the hundreds of millions of dollars for lengthy terms. There indeed is a "have v. have-not" dichotomy among the NGBs. Suffice it to say, the USOPC, with 14 "worldwide" and 21 "domestic" sponsors ${ }^{218}$ and USATF with a huge Nike sponsorship constitutes the "halves." Others, like USA Badminton, did not have any sponsorship agreements. ${ }^{219}$ Yet, accurate information as to the amounts of the sponsorship fees given to NGBs are not readily available.

As part of the funding mandate, the USOPC and each of the NGBs receiving federal funding should be required to release all sponsorship contracts to the commission and, by extension, made available to the public. The agreements should also be disclosed to the members of the respective NGBs before adoption by their boards. While it would remain up to the board to ultimately approve the agreements (or not), it should have a robust debate, which should include an awareness of the viewpoints expressed by the membership before making its decision.

Release of sponsorship agreements are not unique. Public universities often disclose their sponsorship agreements ${ }^{220}$ and that does not seem to have dissuaded sponsors like Nike, which has lucrative deals with public institutions such as the University of Michigan, Ohio State University, and the University of Texas. ${ }^{221}$

\section{Uniform Term Limits for USOPC and NGB Board Members}

The Commission may wish to consider uniform term limits as a way to effectuate change in the respective operations of these boards. The term limits could be term maximum (e.g., two terms) or a "time" maximum (e.g., 10 years). There are pros and cons in determining whether terms limits should be mandated, but at the USOPC and many NGBs, there are time limits. The USOPC has a limit of eight years for directors, but not for the CEO. ${ }^{222}$ For USA Track \& Field, the respective term maximum is also eight years. ${ }^{223}$ The commission may wish to adopt a uniform standard for the USOPC and all of the NGBs, or may wish to modify the time periods based on its best judgment.

\footnotetext{
218 See Team USA Sponsors, https://www.teamusa.org/sponsors (accessed May 30, 2020).

219 See Team USA - Badminton, https://www.teamusa.org/usa-badminton (accessed May 30, 2020).

220 See Mark Synder, Michigan Finalizes Contract with Nike for up to \$173.8 Million, Detroit Free Press, April 26, 2016, https://www.freep.com/story/sports/college/university-michigan/wolverines/2016/04/26/michigan-nike-contract/83533954/ (accessed May 17, 2020). The articles gives a detailed breakdown as to the terms of the agreement and access to the actual document.

221 Id.

222 See Bylaws of the United States Olympic Committee, \$3.6.1 (2018)

223 See USATF, Governance Handbook and Bylaws, §11(d) (2018).
} 


\section{Compensation of Key USOPC and NGB Employees}

As noted earlier, the compensation of certain members of the USOPC and NGBs has been quite generous, often above standard compensation schemes for nonprofits. $^{224}$ This has caused considerable criticism in the press, by victims of sexual abuse (many of whom are currently in litigation against the USOPC), and by Olympic reformers. ${ }^{225}$ The commission should set parameters for compensation. It could take several approaches. First, it could recommend uniform compensation standards for various positions, such as the CEO, Chief Marketing Officer, and other executive ranks. It could also adopt guidelines recommended for CEOs of charitable non-profits by the U.S. Treasury. ${ }^{226}$ The three-part standard would include the commission determining: (1) whether the compensation arrangement was approved in advance by an authorized body (e.g., the board of the USOPC or NGB); (2) whether the individuals in that body who approved the transactions did not have any conflicts of interest concerning the transaction; and (3) whether the body obtained and relied upon appropriate data as to comparability, and adequately and timely documentation to justify its determination. ${ }^{227}$

Finally, the commission could adopt standards of compensation set by the Federal Office of Personnel Management (“OPM"). The OPM sets compensation rates for various types of federal positions, including members of the U.S. executive, legislation, and judicial branches. ${ }^{228}$ The commission could consider the pay rates found in the Rates of Basic Pay for Employees in Senior-Level and Scientific or Professional Positions for certain high level positions ${ }^{229}$ or the rates for Senior Executive Service ${ }^{230}$ in helping formulate a standard. The commission

\footnotetext{
224 See notes 213-216.

225 See Sally Jenkins, Congress Must Fix the USOC and that Includes Exorbitant Executive Spending, The WAsh. Post, March 28, 2018, https://www.washingtonpost.com/sports/olympics/congress-must-fix-the-usoc-and-that-includes-exorbitant-executive-spending/2018/03/26/ a051c898-3128-11e8-94fa-32d48460b955 story.html (accessed May 30, 2020).

226 See IRS, Charities and Nonprofits, Rebuttable Presumptions - Intermediate Sanctions, irs.gov, https://www.irs.gov/charities-non-profits/charitable-organizations/rebuttable-presumption-inter-

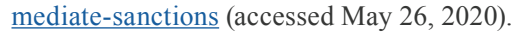

227 Id.

228 See 2020 Executive \& Senior Level Employee Pay Tables, OPM.gov., https://www.opm.gov/ policy-data-oversight/pay-leave/salaries-wages/2020/executive-senior-level/ (accessed May 26, 2020).

229 See Office of Personnel Management, Salary Table No. 2020-SL/St, Rates of Basic Pay for Employees in Senior-Level (SL) and Scientific or Professional (ST) Positions, Jan. 2020, https:// www.opm.gov/policy-data-oversight/pay-leave/salaries-wages/salary-tables/pdf/2020/SLST.pdf (accessed May 26, 2020).

230 See Office of Personnel Management, Salary Table No. 2020-ES Rates of Basic Pay for Members of the Senior Executive Service (SES), Jan. 2020, https://www.opm.gov/policy-data-oversight/pay-leave/salaries-wages/salary-tables/pdf/2020/ES.pdf (accessed May 26, 2020), (lists salary rates from $\$ 131,000$ to $\$ 197,000)$.
} 
could also recommend compensating athletes who serve on the USOPC and NGB boards and committees. That may create a large pool of athletes interested in serving on those committees.

\section{Improving Medical Insurance Options for Olympic Athletes}

The USOPC does offer medical insurance for elite athletes. Titled "Elite Athlete Health Insurance" ("EAHI"), these policies are preferred provider organization ("PPO") plans that are common to many medical insurance plans offered by employers. ${ }^{231}$ Premiums are paid in full by the USOPC for athletes-only policies, but athletes have to pay a relatively small portion of policies that include family members. $^{232}$

Detailed information outlining the scope of the coverage was not found, and it is possible that this insurance plan may provide adequate coverage for the majority of athletes covered. However, the commission would have the power to investigate the levels of coverage and, in consultation with athletes or athlete representatives, look into different plans or require certain kinds of coverage. The issue may be particularly acute with regard to mental health coverage (a problem with many medical insurance plans). ${ }^{233}$ Due to the COVID-19 pandemic, the mental health issues of elite athletes are particularly acute due to the

231 See Elite Athlete Health Insurance, Team USA, https://www.teamusa.org/Team-USA-AthleteServices/Medical/Athlete-Health-Insurance (accessed May 21, 2020).

232 Id. The following table lists 2020 amounts paid by athletes and reported to the IRS once athletes enroll in EAHI:

\begin{tabular}{lcccc}
\hline & $\begin{array}{c}\text { 2020 Benefit } \\
\text { Value }\end{array}$ & Paid by Athlete & $\begin{array}{c}\text { 2020 Monthly } \\
\text { Taxable Amount }\end{array}$ & $\begin{array}{c}\text { 2020 Annual } \\
\text { Taxable Amount }\end{array}$ \\
\hline Athlete Only & $\$ 493$ & $\$ 0$ & $\$ 493$ & $\$ 5,916$ \\
Athlete + Child & $\$ 986$ & $\$ 119$ & $\$ 867$ & $\$ 10,404$ \\
Athlete + Spouse & $\$ 986$ & $\$ 143$ & $\$ 843$ & $\$ 10,116$ \\
Athlete + Family & $\$ 1,800$ & $\$ 156$ & $\$ 1,644$ & $\$ 19,728$ \\
\hline
\end{tabular}

233 See Graison Dangor, Mental Health Parity Is Still An Elusive Goal In U.S. Insurance Coverage, NPR, https://www.npr.org/sections/health-shots/2019/06/07/730404539/mental-health-parityis-still-an-elusive-goal-in-u-s-insurance-coverage (accessed May 21, 2020). ("The laws have been partially successful. Insurers are no longer permitted to write policies that charge higher copays or deductibles for mental health care, nor can they set annual or lifetime upper-limits on how much they will pay for such care. But advocates for patients say insurance companies still interpret mental health claims more stringently than those for physical illness ... The insurance industry's own data show a growing gap between coverage of mental and physical care in hospitals and skilled nursing facilities.”) 
cancellation of events and the disruption of their training schedules. ${ }^{234}$ The commission should consider a review of the medical insurance plan and make recommendations to expand and improve coverage. It could consider the proposal by one Olympic reform organization to a system found in the UK that involves a more holistic approach to medicine and athletic training. ${ }^{235}$

\section{Dispute Resolution}

Because of the time and costs of litigation, arbitration has been the strongly preferred method of adjudicating disputes between various stakeholders in the Olympic movement. The original Amateur Sports Act specifically granted arbitration jurisdiction under the rules of the American Arbitration Association ("AAA"). ${ }^{236}$ The AAA is also used as the adjudicator of choice in domestic doping disputes. ${ }^{237}$ The new law eliminates the AAA requirement, giving the USOPC the power to designate the arbitration and mediation provider. ${ }^{238}$ Ideally, the commission should be given that power, but the commission may recommend specific guidelines for other organizations to serve as adjudicators.

Critics of the system have noted the relatively expensive arbitration fees and the expertise and impartiality of the arbitrators. ${ }^{239}$ These criticisms may have some weight because under both the Amateur Sports Act and general federal law, arbitration rulings are "binding" and it is quite difficult to have them vacated

234 See Julie Kliegman, Mentally, That's a Whole 'Nother Ball Game', SI.com, April 29, 2020, https://www.si.com/olympics/2020/04/29/mental-impact-of-the-pandemic-on-athletes (accessed May 21, 2020). ("Elite athletes face a unique challenge. They may feel anything from anxiety and uncertainty to fear and anger to sadness and even grief over the postponement and cancellation of their competitions. Coping, often through trying to re-create some semblance of routine, is its own challenge.")

235 See H. Paul Dijkstra, N. Pollock, R. Chakraverty, J. M. Alonso, Managing the Health of the Elite Athlete: A New Integrated Performance Health Management and Coaching Model, BR. J. Sports Med. 2014 Apr; 48(7): 523-531 (describing describe the systems, processes and implementation strategies to assist the athlete, coach, and support teams to continuously monitor and manage athlete health and performance. These systems facilitate a balanced approach to training and competing decisions, especially while the athlete is ill or injured. They take into account the best medical advice and athlete preference.), cited in Olympians Rising: Recommendations to Congress: Reforming the U.S. Olympic Committee to Ensure Health and Livelihood of Athletes, Sept. 19, 2018, https://b4e28f76-a1fb-478b-b91a-cd0786d4a572.filesusr.com/ugd/6c3074 b899564b76b14e989567335d0a9b4406.pdf (accessed May 18, 2020).

23636 U.S.C. $\$ 220529$ (a).

237 See Maureen A. Weston, Simply a Dress Rehearsal? U.S. Olympic Sports Arbitration and De Novo Review at the Court of Arbitration for Sport, 38 GA. J. InT'L \& Comp. L. 97, 107.

238 See S. 2330, sec. 7. ("accordance with the standard commercial arbitration rules of an established major national provider of arbitration and mediation services based in the United States and designated by the corporation with the concurrence of the Athletes' Advisory Council and the National Governing Bodies' Council.”)

239 See Committee to Restore Integrity to the USOC, n. 149 
by the courts. ${ }^{240}$ Many cases brought by athletes have involved eligibility issues and there is good reason to keep the system as it is. Arguably, arbitration is a preferred method rather than litigation for such cases due to timeliness issues.

For example, the commission could establish its own group of arbitrators based on standards of experience, knowledge of the Olympic system, and general expertise in dispute resolution. It may recommend arbitration by three-person arbitration panels whereby each party would get to appoint an arbitrator with the third arbitrator considered a "neutral" arbitrator appointed by the commission. It could also propose a training system or certification system for potential arbitrators to ensure that the arbitrators are knowledgeable about the issues particular to sports cases, especially those with regard to Olympic eligibility, governance issues, and doping. Or it can keep the system as it is.

\section{Creation of an Independent Ethics Board for the USOPC and the NGBS}

The USOPC and the NGBs have ethics committees, whose members are appointed by board members of those very organizations (a system in place since its creation in 2005). ${ }^{241}$ The responsibilities of the ethics committee include overseeing compliance with the USOPC Code of Conduct, recommendations for revision of the Code of Conduct, reviewing the organizational structure of the USOPC, and reviewing the handling of ethics-related compliance, or if directed by the Board, directly handling those complaints (emphasis added). ${ }^{242}$ There is also a conflict of interest policy that generally requires USOPC board members, employees, and volunteers to disclose potential conflicts of interest, such as owning a business that provides goods or services to the USOPC or any NGB, or, more generally, participating in activities or maintaining interests "that interfere with the satisfactory performance of USOPC work assignments." 243

The interrelationship between the USOPC's board and its ethics committee may hurt the independence of the ethics committee. Some NGB ethics committees have the same problem. As an alternative, the commission may consider the creation of an independent ethics board to oversee the USOPC and all the NGBs,

\footnotetext{
240 See 36 U.S.C. $\$ 220529$ (d); See also Federal Arbitration Act, 9 U.S.C. $\$ 10(a)$. Court will vacate arbitration awards in rare circumstances, such as when an arbitrator exceed his or her authority, or engaged in fraud or "evident partiality." See also, Gault v. United States Bobsled and Skeleton Federation, 578 N.Y.S.2d 683, 685 (N.Y. App. Div. 1992).

${ }^{241}$ See Bylaws of the United States Olympic and Paralympic Committee, sec. 5.5 .1 (2020) ("The Nominating and Governance Committee shall appoint the members of the Ethics Committee other than its chair. The chair of the Ethics Committee shall be a member of the Board, appointed by the Chair with approval of the board.")

242 Id. at 5.5.3.

${ }^{243}$ See U S Olympic \& Paralympic Committee Policy. Feb. 27, 2020, https://www.teamusa.org/ Footer/Legal/Governance-Documents (accessed May 21, 2020).
} 
or perform that function itself. In either case, athletes and other stakeholders can report potential violations of ethics, which will be promulgated by the new board or the commission These rules can override any inconsistent internal rules of the USOPC and respective NGBs. In promulgating these rules (which would go through a process similar to rules and regulations promulgated by administrative agencies under the Administrative Procedure Act ("APA"), the Commission can have a public comment process where the public, athletes, coaches, and the representatives of the governing bodies can post their views. ${ }^{244}$

It is noteworthy the USOPC's own athletic representative, Han Xiao, in his Senate committee testimony, proposed the creation of an independent oversight committee "to evaluate the business practices of the USOPC, provide recommendations to the USOC Board of Directors, and report directly back to Congress." 245 The commission should go a step further and take control of the oversight process by the appointment of the independent board or boards (depending on which approach is taken). The commission should set the standards for members of this board and could send a public notice seeking candidates for a seat on this ethics board.

\section{Reforms that the Commission on the State of U.S. Olympics and Paralympics Could Recommend to Congress}

Under the 2020 Act, the commission has the jurisdiction to propose the reforms noted previously. However, the commission could make recommendations to Congress to change existing law. These recommendations are admittedly more radical but worth considering.

\section{Athletes' Rights to Information Under the Freedom of Information Act}

The Freedom of Information Act (FOIA) ${ }^{246}$ provides the public the right to request access to records from any federal agency. Federal agencies are required to disclose any information requested under the FOIA unless it falls under one of nine exemptions that protect interests such as personal privacy, national security, and

\footnotetext{
244 See 5 U.S.C. sec. 551 et seq.

245 See Xiao, Han. Testimony before the U.S. Senate Commerce Committee Subcommittee on Consumer Protection, Product Safety, Insurance, and Data Security, ON THE FUTURE OF ATHLETE SAFETY: "Strengthening and Empowering U.S. Amateur Athletes: Moving Forward with Solutions" July 24, 2018. Alternatively, Congress could appoint several members of the USOC Board of Directors in a bi-partisan manner. Both models would provide more outside perspective to the USOC's governance structure without significantly impacting the stability of the organization. Id..

246 5 U.S.C. § 552. See also FOIA Improvement Act of 2016, Public Law 114-186 (June 30, 2016) (liberalizing some of the procedures of the original act, such as making records available in electronic format.)
} 
law enforcement. ${ }^{247}$ The commission could recommend amendments conferring jurisdiction on the USOPC and the NGBs to FOIA actions by individuals. For example, gymnasts seeking records from USA Gymnastics regarding records involving sexual abuse by coaches should be permitted access before having to engage in litigation and going through the civil discovery process.

\section{Amending the Labor Laws to Permit the Unionization of Elite Athletes}

In the wake of the sex abuse scandals that rocked gymnastics, some scholars have advocated the unionization of members of national Olympic teams as a way for those athletes to have greater protection from abuse. ${ }^{248}$ However, there are hurdles to unionizing under the National Labor Relations Act ("NLRA"), ${ }^{249}$ because questions arise about whether these elite athletes can be considered "employees." While this issue has been debated with some frequency in the case of college athletes (which resulted in one notable National Labor Relations Board ruling), ${ }^{250}$ it has not been addressed with respect to Olympic athletes. But it should. While this topic could be the subject of a separate article, it is worth a short discussion.

The NRLA does not explicitly state who is an "employee." Rather, it states that anyone considered an independent contractor is not an employee and not

${ }^{247}$ See What is FOIA? Foia.gov, https://www.foia.gov/about.html (accessed May 17, 2020). For the exceptions, see FOIA Exceptions, Department of Homeland Security, https://www.dhs.gov/ foia-exemptions (they include: classified information in the interest of national security; records related solely to the internal personnel rules and practices of an agency; information exempted from release by statute; trade secrets and commercial or financial information which could harm the competitive posture or business interests of a company; opinion, conclusions, and recommendations included within inter-agency or intra-agency memoranda or letters; information that would constitute a clearly unwarranted invasion of personal privacy of the individuals involved, such as security numbers, home addresses, and telephone numbers of employees; certain records or information compiled for law enforcement purposes, such as endangering the life or physical safety of an individual; information that is contained in or related to examination, operating, or condition reports prepared by, on behalf of, or for the use of an agency responsible for the regulation or supervision of financial institutions; geological and geophysical information and data, including maps, concerning wells.

248 See Marc Edelman and Jennifer M. Pacella, Vaulted into Victims: Preventing Further Sexual Abuse in U.S. Olympic Sports Through Unionization and Improved Governance, 61 ARIz. L. REv. 463 (2019) ("creation of a formal union body to represent and protect the interests of the young athletes who compete within each individual, amateur sport in this nation.")

249 See 29 U.S.C. $\$ 151$ et seq.

250 See Northwestern University and College Athlete Players Association (CAPA), 362 NLRB No. 167 (2015) ("On March 26, 2014, the Regional Director issued a Decision and Direction of Election in which he found that all football players receiving a grant-in-aid scholarship are employees within the meaning of Section 2(3) of the Act. ... The Board then stated that it had determined that, even if the scholarship players were statutory employees (an issue the Board emphasized it was not deciding), it would not effectuate the policies of the Act to assert jurisdiction.”) 
protected under this law. ${ }^{251}$ Because of this lack of a more specific definition, courts and the National Labor Relations Board ("NLRB") have crafted their own standards, which may be difficult for a group of athletes on an Olympic or championship team to attain. Although there are scholars who think so, this author remains skeptical.

The common-law definition for an "employee" includes any person who "performs services for another under a contract of hire, subject to the other's control or right of control, and in return for payment." ${ }^{252}$ Members of, say, the U.S. Olympic Swimming team would not fit this definition since: (1) they were chosen to represent the US but not "hired" to do so under an employment contract; and (2) they receive no salary, but only a bonus if any one or more of the team members medal. It makes little sense to fight a challenge at the NLRB or in the courts, which will be costly and time-consuming.

Instead, it is easier to enact a provision in the NLRA mandating that such athletes should have the right to unionize and that representatives could negotiate collective bargaining agreements ("CBAs") dealing with respect to working conditions and protections from abusive coaching and sexual abuse. A CBA could mandate penalties against the governing bodies and the USOPC and grant protection against retaliation if an athlete accuses a coach or other team managers of sexual or emotional abuse. It could also allow the athletes the right to strike, a right, albeit highly unlikely, to be exercised by many athletes barely past the age of majority (and some below that age) and because they would not want to sacrifice the allure and honor of being on an Olympic or world championship team.

So, this solution is not without risk. It could lead to difficulties in team cohesion and false allegations that could upend the team in the preparation of the competition. Conceivably, it could significantly change the governance of the USOPC and the NGBs because the union may require the termination of the various athletes' advisory committees found in these organizations.

\section{Ending Special Trademark Protection for the USOPC and the NGBS}

As noted earlier, the Sports Act included enhanced trademark protection as a way for these bodies to monetize their marks. With a governmental funding regime, there is little reason to grant enhanced trademark protection, which limited statutory defenses to those accused of unauthorized uses and to eliminate the likelihood of confusion requirement. Instead, amending the Sports Act (or

\footnotetext{
251 See 29 U.S.C. $\$ 152(3)$.

252 See Brown Univ., 342 NLRB Dec. (CCH) 483, 500, n. 27 (2004) (citing NLRB v. Town \& Country Elec. Inc., 516 U.S. 85, 94 (1995)). For more explanation and analysis, see Edelman and Pacella, supra at 61 Ariz. L. Rev AT 484.
} 
including a provision in the Lanham Act $^{253}$ overriding this provision) would treat the USOPC and the NGBs like any other trademark holder.

\section{The Appointment of an Inspector-General}

The commission should consider the appointment an inspector general intended to be an independent, nonpartisan official whose aim is to prevent and detect waste, fraud, and abuse in the operations of the USOPC and the NGBs. ${ }^{254}$ It may look to the standards derived from the Inspector General Act of 1978 and related amendments, which expanded the scope of the duties of one in the position. ${ }^{255}$

Amendments enacted in $1998^{256}$ and $2016^{257}$ are applicable to this discussion. The 1998 amendments created a category of inspector generals for "designated federal entities" (DFEs), which could include the aforementioned Olympic bodies, thereby granting greater powers to inspector generals. ${ }^{258}$ The latter amendments allow inspector generals to conduct computerized data comparisons across different agency automated record systems without restrictions in the law. ${ }^{259}$ If appointed under this authority, the inspector general would be granted the power to compare how the various Olympic bodies run their operations and it may be a way to determine which agencies are more efficient and more transparent than others.

For example, if NGB A has a payroll five times that of NGB B, but with the same number of members of similar numbers of affiliated organizations, that may be something to pique the inspector general's interest. If NGB C has paid what seems to be an unusually large sum for its website as compared with other NGBs, that also may be a matter of interest. This does not mean that the NGBs in question are engaging in improper activities per se, but it will give the outside inspector general the power to review. Internal documents dealing with the reporting (or non-reporting) of sexual or other abuse by coaches and other personnel would be reviewable, and those claiming abuse would not have to wait to litigate and go through discovery to find out.

The inspector general could have the power to engage in periodic performance audits, inspections or evaluations, and investigations. For example, a performance audit would include whether the USOPC and NGBs comply under generally acceptance of rules regarding the conduct and fiduciary duties of the

\footnotetext{
253 See 15 U.S.C. $\S 1051$ et seq.

254 See Statutory Inspectors General in the Federal Government: A Primer, Congressional Research Service, Jan. 3, 2019, p. 1, https://fas.org/sgp/crs/misc/R45450.pdf (accessed May 20, 2020). 
CEO, board, and officers. The focus would be primarily on alleged misuse or mismanagement of the organization's programs, and effectiveness of their internal controls. ${ }^{260}$ Specifically, the inspector general would have access to records and information related to the affiliated entity's programs and operations, have the power to subpoena information and documents, and administer oaths when conducting interviews. ${ }^{261}$ If criminal activity is suspected, the information may be turned over to the Justice Department for possible prosecution. The inspector general may need a small staff to aid in investigations and audits of the USOPC and the 40-plus NGBs. The inspector general would be obligated to file an annual report to both Congress and to the Commission for Olympic and Paralympic Sports. Funding would come from Congress.

The importance of an inspector general in the Olympic sphere was aptly summed up by Han Xiao, Chair of the USOPC Athlete Advisory Council, who stated in testimony to the Senate that an inspector general would "preserve the anonymity of athletes, providing protection for whistleblowers," allow for proactive investigations, and reduce legal costs to all parties. ${ }^{262}$ The idea for an independent inspector general has been sought by both The Committee to Restore Integrity to the USOC and Olympians Rising, the most prominent groups seeking change in the Olympic structure. ${ }^{263}$

\section{State Actor Status}

The DeFrantz and San Francisco Arts and Athletics rulings made clear that the USOPC in its present form is not a state actor. ${ }^{264}$ It may be possible that a court may confer state actor status due to the role of the commission depending on the scope of its powers. Admittedly, this is a questionable proposition, but at the very

\footnotetext{
260 Id. at p. 9-10.

261 See 5 U.S.C. Appendix (IG Act) $\S \S 3(a), 6(a), 6(e)$, and 7..

262 He added that the appointment of an independent inspector general would "Allow for the investigation of other issues that arise outside the protections afforded by the Sports Act; Assist in proactively identifying issues within NGBs and the USOC, including possible corrective actions; Contribut[e] to more routine and proactive oversight of the USOC and the entire Olympic and Paralympic system; Improv[e] the athletes' and the American public's trust in USOC and NGB governance; Reduc[e] legal costs for all parties due to the reduction in necessary Section 10 hearings and their binding arbitrations when the Inspector General intervenes." See Xiao, Han, Testimony before the U.S. Senate Commerce Committee Subcommittee on Consumer Protection, Product Safety, Insurance, and Data Security, On the Future of Athlete Safety: "Strengthening and Empowering U.S. Amateur Athletes: Moving Forward with Solutions” July 24, 2018.

263 See Committee to Restore Integrity, n. 134. See also, Olympians Rising: Recommendations to Congress: Reforming the U.S. Olympic Committee to Ensure Health and Livelihood of Athletes, Sept. 19, 2018, https://b4e28f76-a1fb-478b-b91a-cd0786d4a572.filesusr.com/ugd/6c3074 b899564b76b14e989567335d0a9b4406.pdf (accessed May 18, 2020).

264 See n. 138.
} 
least, the 1998 amendment of the Sports Act barring private actions (including state action claims) should be removed. Even if that is the case, a second issue is presented: whether such challenges can be limited by contract or by arbitration clause as in the case of private business agreements? ${ }^{265}$

With regard to allegations of violations of due process regarding eligibility requirements for inclusion for an Olympic, Paralympic, or world championship team, it may be possible that the Sports Act or the commission consider restricting those rights to arbitration. There are good reasons for this, mainly the timeliness of such claims and the lack of expertise of judges to make such determinations. In any event, this question may be moot because even if athletes could bring those particular claims, they would likely be dismissed because participation in the Olympics or in world championships are not "rights" but "privileges." 266 The bigger question is whether an athlete could challenge policies that may affect their free speech rights.

The nationwide protests in 2020 by those under the "Black Lives Matter" movement that rocked the nation also forced a reckoning on race in society. In the sports world, more athletes engaged in "taking a knee" during the national anthem. ${ }^{267}$ Private actors, such as the National Football League and National Basketball Association, could restrict such a practice, and not be subject to a constitutional challenge. ${ }^{268}$ However, in the case of athletes doing the same at an Olympic Trials sanctioned by an NGB, they could be subject to First Amendment challenges in court. For example, the USOPC could be sued if it decides that athletes cannot engage in protest activities during the playing of the national anthem at a medal ceremony - an issue that has come up at a recent Pan American Games, where one athletes raised a fist and the other kneeled at a medal

\footnotetext{
265 See Roberts v. AT\&T Mobility LLC, 877 F.3d 833 (9th Cir., 2017 (state action claim regarding arbitration clause between a private firm and a consumer on grounds that it involves a permissive state statute rejected).

266 See DeFrantz v. USOC, 492 F. Supp. 1181 (D.D.C. 1980).

267 See John Branch, The Anthem Debate Is Back. But Now It's Standing That's Polarizing, N.Y.

Times, July 4, 2020, https://www.nytimes.com/2020/07/04/sports/football/anthem-kneeling-sports. html (accessed July 6, 2020) ("The stand-or-kneel debate, sparked by Colin Kaepernick's posture during the national anthem in 2016 and smoldering since, has reignited - bigger than before, and this time with an unexpected twist. Today, athletes may have to explain why they chose to stand, not kneel, during 'The Star-Spangled Banner."').

268 See Paul Callan, There Is No Constitutional Right to Take a Knee While You're at Work, CNN. com, Sept. 26, 2017, https://www.cnn.com/2017/09/26/opinions/first-amendment-football-protest-callan-opinion/index.html ("The Founding Fathers made no mention of restricting the right of the National Football League or any other private employer to "prohibit" or "abridge" the freedom of speech.")
} 
ceremony to protest racism in the US. ${ }^{269}$ Some circuits have explicitly permitted such a limitation to a First Amendment challenge, as long as the agreement is "knowingly" and "voluntarily" made. ${ }^{270}$ At this time, such restrictions are possible, although not in the best interests of the athletes. This is a complex matter that has scant jurisprudence, and a full examination would be the subject of a separate article. Suffice it to say, the doctrine is unclear. ${ }^{271}$

\section{Standards for Determining Sexual and Physical Abuse by USA SafeSport and the 2020 Act}

The present incarnation of the U.S. Center for SafeSport was established in 2017 with the purpose of "preventing all forms of abuse in sport," soon after the passage of the Protecting Young Victims from Sexual Abuse and Safe Sport Authorization Act of 2017. ${ }^{272}$ It is organized as an independent nonprofit organization based in Denver, Colorado, designated by the U.S. Congress to respond to reports of sexual misconduct within U.S. Olympic and Paralympic sports.

Under the SafeSport Act, the center develops resources and policies to safeguard athletes from bullying, harassment, hazing, physical abuse, emotional abuse, sexual abuse, and sexual misconduct. ${ }^{273}$ The law entrusts the center as the exclusive authority to respond to reports of allegations of sexual abuse and sexual misconduct within the USOPC and their recognized NGBs. Its most important role is to engage in background checks on coaches and other support personnel and it maintains the exclusive jurisdiction to investigate and resolve allegations

\footnotetext{
269 See Derrick Bryson Taylor, U.S. Fencer and Hammer Thrower Lead Silent Protests at Pan-American Games, N.Y. Times, Aug. 11, 2019, https://www.nytimes.com/2019/08/11/sports/ race-imboden-fencer-kneels.html (accessed May 22, 2020) ("The United States fencer Race Imboden took a knee at the awards ceremony of the Pan-American Games on Friday, and the next day, the hammer thrower Gwen Berry raised her fist during the national anthem in a pair of silent political protests that officials said could have consequences.").

270 See, e.g. Snepp v. United States, 444 U.S. 507, 508 (1983) (Court upheld contract provision signed by former CIA agent not to publish any information relating to his employment without government approval, concluding it was within the CIA's power). See also Scott, at n. 306.

271 See Brittany Scott, Waving Goodbye to First Amendment Protections: First Amendment Waiver by Contract, 46 Hastings Const. L. Quart. 451, 453 (2019) (“The Court rarely overtly discusses First Amendment waiver in its opinions. It is somewhat baffling that the Court has been willing to articulate a waiver test in other constitutional rights cases but has not expressly articulated a standard for evaluating First Amendment waiver.")

272 Public Law No: 5-126 (February 14, 2018).

${ }^{273}$ See A Federally Authorized Resource to End Abuse, U.S. Center for SafeSport, https://uscenterforsafesport.org/about/our-work/ (accessed April 4, 2020).
} 
that a "participant" engaged in sexual misconduct and child abuse, ${ }^{274}$ and discretionary jurisdiction to investigate and resolve allegations that a participant engaged in other, non-sexual child abuse. ${ }^{275}$ Congress has taken a hand-off approach in terms of governance and financing of the organization, resulting in the USOPC exercising a great deal of control, even dominance, despite the ostensibly independent nature of the organization. ${ }^{276}$ At least one governing body, however, questioned whether there is a need for a centralized organization like SafeSport, arguing that it could adequately police abusive conduct, despite having its own sex abuse issues. ${ }^{277}$

The center coordinates with law enforcement for potential criminal investigations, but its internal governance involves a hearing process and a range of sanctions, from a warning to permanent ineligibility to participate in the sport. ${ }^{278}$ There is an arbitration procedure if a party wishes to contest the determination of the center. ${ }^{279}$ As noted, while most actions have involved sexual abuse inves-

\footnotetext{
274 See U.S. Center for SafeSport, SafeSport Code for the U.S. Olympic and Paralympic Movement (2020), Arts. IV A and B; Art. VIII J (accessed April 4, 2020). The organization has the exclusive authority to respond to allegations of sexual abuse and sexual misconduct, but it also has the discretion to investigate other violations of the SafeSport code, like bullying, harassment, and physical and emotional abuse. After a report is filed, the center evaluates whether it will take the case. If it chooses not to, the report goes back to the NGB and the sport's officials can choose to pursue it either by investigating internally or hiring an outside investigator. In rare circumstances the center may investigate a report of emotional or physical abuse. For more information, see Erin Strout, What Is SafeSport and Why Did It Suspend Alberto Salazar?, Women's Running, Feb. 5, 2020, https://www.womensrunning.com/culture/what-is-safesport-and-why-did-it-suspend-alberto-salazar/ (accessed April 5, 2020)

275 Id.

276 See Diana Moskowitz, SafeSport, the USOC's Attempt to Stop Child Abuse, Is Set Up to Fail - Just Like It Was Supposed To, DeADSPin, July 24, 2018, https://deadspin.com/safesport-the-usocsattempt-to-stop-child-abuse-is-se-1826279217 (accessed April 4, 2020).

277 See David W. Chen, A Tennis Coach Was Abusing Minors. Should the Sport's Federation Have Known?, N.Y. Times, April 4, 2020, https://www.nytimes.com/2020/04/04/sports/tennis/ tennis-sex-abuse-safesport.html (accessed April 5, 2020). ("Gordon Smith, the tennis association's executive director and chief operating officer at the time, ... objected to a "single mandatory national entity" overseeing abuse cases across federations and, over the objections of representatives for gymnastics, volleyball, and wrestling, he said that a sport should be able to 'opt out of the centralized structure' if it could police itself ... Whether the U.S.T.A. could police itself, though, was another matter ... Just months earlier, a prominent U.S.T.A. coach from the Bay Area had been arrested a second time on charges of abusing one of his teenage players.")

278 See SafeSport Code, Art. XIII A.

${ }^{279}$ Id. at Art. XIV
} 
tigations, one prominent track and field coach was suspended by the center for non-sexual abuse of a teenage runner. ${ }^{280}$

Until the passage of the 2020 Sports Act, the organization was seriously underfunded. In its 2018 tax return, it reported revenues of over \$6 million, but salaries and expenses took a hefty portion of that amount. ${ }^{281}$ Salaries alone were close to $\$ 1$ million and legal fees another $\$ 647,000 .{ }^{282}$ Much of the funding comes from the USOPC, and the center has been justifiably criticized not only for the inadequate funding, but for its lack of independence. ${ }^{283}$ In fact, in its first year of formal operation, most attendees of its meetings were USOC officials. ${ }^{284}$ By comparison, the U.S. Anti-Doping Agency had a \$20 million budget in 2016, while SafeSport was less than one fifth of that ${ }^{285}$ and could have been one reason for a backlog of cases. As of early 2020, the Center for SafeSport received more than 200 reports a month, had an estimated 1,100 open cases, and only 18 investigators and lawyers. ${ }^{286}$

280 See Strout, n. 174 (coach was temporarily suspended for "allegations of misconduct" after middle distance runner Mary Cain released an opinion video claiming she was emotionally and physically abused by Salazar. [note: Ms. Cain was a student in one of my classes at Fordham and has since been a guest speaker in my classes since her graduation; however, I was not involved in her decision to go public, nor was I aware of the allegations she made before her public statements.]). 281 See U.S. Center for SafeSport, Return of Organization Exempt from Income Tax, IRS Form 990, https://uscenterforsafesport.org/wp-content/uploads/2019/09/2018-990.pdf (accessed April 4, 2020).

${ }^{282} I d$. at pp. 7 and 8 . Another $\$ 165,000$ went to computer software and $\$ 150,000$ went to a firm who served the help desk.

${ }^{283}$ Id. ("Even before the center opened its doors, Hogshead-Makar, CEO of ChampionWomen, and Marci Hamilton, CEO of Child USA and a professor at the University of Pennsylvania, had sent multiple letters critiquing the proposed SafeSport code that the center would be in charge of enforcing. One stated: "We understand that SafeSport board and staff will only be working for the new organization. Still unaddressed: What are the rules of SafeSport employment for those who have previously been affiliated with the organizations that SafeSport will be investigating? It is our view that "independence" can only be achieved if former USOC/NGB and Coaching Association employees and consultants have at least a two-year separation time before employment or engagement with SafeSport.")

284 See Philip Hersh, The John Coughlin Story, Tragic for All Involved, Should Lead to Empathy and Understanding Instead of Finger-Pointing, Globetrottingbyphilliphersh.com, Jan. 23, 2019, http://www.globetrottingbyphiliphersh.com/home/2019/1/22/the-john-coughlin-story-tragicfor-all-involved-should-lead-to-more-than-finger-pointing (accessed May 30, 2020). ("Although SafeSport is independent, others feel it is not independent enough from the USOC, which established SafeSport and provides much of its funding.")

${ }_{285}$ Id. In 2016, SafeSport received about \$2 million, while USADA received over \$12 million. See also Senate Report 113-281, 113th Congress, 2d Session, UNITED STATES ANTI-DOPING AGENCY REAUTHORIZATION ACT, Report of the Committee on Commerce, Science, and Transportation on S. 2338, Dec. 1, 2014, https://www.govinfo.gov/content/pkg/CRPT-113srpt281/ html/CRPT-113srpt281.htm (accessed May 17, 2020).

286 Id. 
Critics complained that investigations took too long, and the results have been inconsistent. ${ }^{287}$ One coach's suspension came 15 months after the case was referred to the Center for SafeSport by USA Gymnastics and 32 months after USA Gymnastics first investigated the coach and her gym. ${ }^{288}$ In addition, they have cited inconsistencies in sanctions for seemingly similar cases. ${ }^{289}$ On the other hand, others have criticized what they deem is a lack of proper due process by the group before making a determination of abuse and punishment. ${ }^{290}$ The 2020 Sports Act addresses some of the criticisms of SafeSport. Under the new law, funding would jump to $\$ 20$ million a year. The law extends certain procedural due process protections to those accused of transgressions, notably a "preponderance of the evidence" standard for adjudication. ${ }^{291}$ Both of these reforms may allay some of the criticisms of the Center for SafeSport. The commission could make additional recommendations regarding the scope and powers of the organization, depending on how successful the changes in the 2020 Act may be.

\footnotetext{
287 See Grace Kier, Three Years On, Center for SafeSport Faces Controversy, Pulitzer Center, April 20, 2020, https://pulitzercenter.org/reporting/three-years-center-safesport-faces-controversy (accessed May 28, 2020).

288 See Scott M. Reid, SafeSport: Amy Nyman Made Gymnasts Feel 'Scared, Degraded and Humiliated', Orange County Register, May 28, 2020, https://www.ocregister.com/2020/05/28/ safesport-amy-nyman-made-gymnasts-feel-scared-degraded-and-humiliated/ (accessed May 28,2020 ) ('Gymnasts and their families' anxiety about the case was further heightened, parents said, by how long it took to resolve and by SafeSport investigators' failures to respond to emails, phone calls and texts in a timely manner - if they responded at all. An attorney for Nyman also complained about the length of the case.")

289 Id.

290 See Grace Kier, Three Years On, Center for SafeSport Faces Controversy, Pulitzer Center, April 20, 2020, https://pulitzercenter.org/reporting/three-years-center-safesport-faces-controversy (accessed May 28, 2020).

291 See The Empowering Olympic, Paralympic, and Amateur AthletesAct and Response \& Resolution, US Center for SafeSport, https://uscenterforsafesport.org/wp-content/uploads/2020/10/ Response-and-Resolution-S2330.pdf (accessed Nov. 16, 2020). These include: 1. The provision of written notice of allegations against the Respondent; 2 . The right to be represented by counsel or other advisor; 3. An opportunity to be heard during the investigation; 4. A reasoned decision from the Center if a violation is found; 5. The ability to challenge through arbitration any temporary measures or sanctions imposed by the Center.
} 


\section{Conclusion}

Many stakeholders in the U.S. Olympic movement have dedicated their lives and careers in furtherance of U.S. Olympic sports. Their efforts have achieved athletic success. U.S. Olympic medal counts have never been higher. A few medalists have been able to secure lucrative endorsements and become respected public figures. Training facilities are much improved. Athletes at least have some seats at the table. Ethics and transparency are taken more seriously. Sponsors have brought in money to provide a cushion for certain organizations to grow. And some NGBs have avoided controversy and scandals.

But so much more should be done. Governance problems continue. Some Olympic and NGB leaders receive all-to-generous compensation. There is an overdependence on sponsor money. And, most significantly, a lack of serious athlete rights, culminating in the sexual abuse scandals. The fact that Congress enacted the 2020 Empowering Olympic, Paralympic and Amateur Athletes Act meant that these incremental reforms did not far enough.

The sexual abuse scandals painfully exposed the governance flaws in the Olympic system. The COVID-19 pandemic exacerbated the funding problems found in U.S. Olympic sports and introduced the uncertain status of college programs that aid in developing athletes for the Olympics.

The CEOs, directors, officers, and employees do not have an easy job. Managing the various stakeholders in a diverse and complex system is challenging. To be fair, Sarah Hirshland of the USOPC has earned some positive reviews from athletes. ${ }^{292}$ For example, she created an athlete-led group "to challenge the rules and systems" in the USOPC "that create barriers to progress, including your right to protest." ${ }^{293}$

However, the establishment of and the mandate of the Commission on the State of U.S. Olympics and Paralympics under the new law may be the best way to reimagine American Olympic sports as a better managed, better funded, better scrutinized system to protect all of its stakeholders. Government funding would greatly help bring more financial security and less dependency on sponsors and broadcasters. Even if COVID-19 never occurred, the U.S. Olympic sports system was in great need for reform. COVID-19 made that need more compelling.

\footnotetext{
292 See Rachel Bachman, Team USA Chief Says Athletes' Feedback Enabled Call for Delay of Olympics, The Wall Street Journal, March 26, 2020, https://www.wsj.com/articles/team-usachief-says-athletes-feedback-enabled-call-for-delay-of-olympics-11585236262 (accessed June 22, 2020) (“... the improved relationship with athletes - thousands of whom are still coming to grips with having no Summer Olympics this year-is no small feat.”)

293 See Torrey Hart, USOPC Creates Athlete Group to Examine Policies - Including Right to Protest, Swimswam.com, June 9, 2020, https://swimswam.com/usopc-creates-athlete-group-toexamine-policies-including-right-to-protest/ (accessed July 23, 2020).
} 
The Commission on the State of U.S. Olympics and Paralympics may wish to consider the proposals outlined in this article. Adoption of some or all would not only benefit the Olympic movement and the particular NGBs, but would also benefit the athletes who sacrifice so much to compete in the sport. As one athlete advocate put it, the passage of the Empowerment Act "is not the end of the road ... [but] a beginning" in the goal of creating a vibrant [Olympic] system in United States." 294

294 See Rick Maese, Olympics Reform Bill Passes House, Promising Sweeping Change After Abuse Scandals Rocked Sports, The Washington Post, Oct. 1, 2020, https://www.washingtonpost. com/sports/2020/10/01/olympics-reform-bill-house-abuse/ (accessed Oct. 16, 2020) (quoting Eli Bremer, an Olympic modern pentathlete and critic of the USOPC). 